\title{
DOES MEMBERSHIP ON THE UN SECURITY COUNCIL INFLUENCE IMF DECISIONS? EVIDENCE FROM PANEL DATA
}

\author{
AXEL DREHER \\ JAN-EGBERT STURM \\ JAMES RAYMOND VREELAND \\ CESIFO WORKING PAPER NO. 1808 \\ CATEgORY 2: Public CHOICE \\ SEPTEMBER 2006
}

An electronic version of the paper may be downloaded
- from the SSRN website: $\quad$ www.SSRN.com
- from the RePEc website: $\quad$ www.RePEc.org
- from the CESifo website: 


\title{
DOES MEMBERSHIP ON THE UN SECURITY COUNCIL INFLUENCE IMF DECISIONS? EVIDENCE FROM PANEL DATA
}

\author{
Abstract \\ We investigate whether temporary members of the UN Security Council receive favorable \\ treatment from the IMF, using panel data for 191 countries over the period 1951 to 2004. Our \\ results indicate a robust positive relationship between temporary UN Security Council \\ membership and participation in IMF programs, even after accounting for economic and \\ political factors, as well as regional and country effects, and duration dependence. There is \\ also evidence that UNSC membership reduces the number of conditions included in IMF \\ programs. The size of the loan, however, is not affected by UNSC membership. \\ JEL Code: F33. \\ Keywords: IMF, UN Security Council, voting, aid. \\ Axel Dreher \\ ETH Zurich, KOF \& \\ Department of Management, Technology \\ and Economics \\ Weinbergstr. 35 \\ 8092 Zürich \\ Switzerland \\ mail@axel-dreher.de \\ Jan-Egbert Sturm \\ ETH Zurich, KOF \& \\ Department of Management, Technology \\ and Economics \\ Weinbergstr. 35 \\ 8092 Zürich \\ Switzerland \\ sturm@kof.ethz.ch \\ James Raymond Vreeland \\ Yale University \\ Department of Political Science \\ USA \\ james.vreeland@yale.edu
}

First version: May 2006

This version: August 2006 


\section{Introduction}

Recent evidence from Kuziemko and Werker (2005) indicates that the ten temporary members of the United Nations Security Council (UNSC) are more likely to receive US foreign aid than other countries. They attribute this increase to vote trading activities: temporary members trade their votes for cash. The argument is related to the broad line of literature analyzing the impact of aid on voting in the UN General Assembly. ${ }^{1}$ Bernstein and Alpert (1971), Rai (1972, 1980), Wittkopf (1973), Lundborg (1998) and Wang (1999) show that when US aid increases, the recipient country is more likely to vote with the US in the General Assembly. ${ }^{2}$ Dreher and Sturm (2006) find that International Monetary Fund (IMF or Fund) involvement in a country is robustly related to voting coincidence in the UN General Assembly between G7 countries and recipient countries. Arguably, Security Council decisions are substantially more important as compared to those of the General Assembly. If the G7 employ the IMF to bribe or reward countries in the General Assembly, we would expect them to use the Fund to turn Security Council decisions in their favor also.

Clearly, the top five IMF shareholders - the US, Japan, Germany, France and the United Kingdom - control the Fund. These members alone control nearly 40 percent of the vote share and are the only countries that automatically have seats on the IMF 24 member Executive Board. The rest of the world vies for representation through elections and shared seats. With about 17 percent of the total votes, the US by itself has veto power over major decisions at the IMF, including the appointment of the IMF Managing Director.

The IMF has been shown to act as a tool of US (and other G7 countries) foreign policy to some extent. ${ }^{3}$ Thacker (1999), for example, shows that governments that vote along the lines of the US on key issues in the United Nations General Assembly are more

\footnotetext{
${ }^{1}$ The empirical literature on UN General Assembly voting is substantial (e.g., Voeten 2000, 2001, 2004). See Boockmann and Dreher (2006) for an analysis of the determinants of countries' voting behavior. There is also substantial literature investigating whether and to what extent committee members generally extract rents from being on committees (see, e.g. Levitt and Snyder, 1997).

${ }^{2}$ However, Kato (1969), Kegley and Hook (1991), Sexton and Decker (1992) and Morey and Lai (2003) do not find evidence in favor of this link. Dreher and Sturm (2006) show that the link between overall US aid and General Assembly voting is not robust to the inclusion of control variables. Dreher, Thiele and Nunnenkamp (2006), however, show that specific aid categories indeed increase voting coincidence.

${ }^{3}$ See Gisselquist (1981), Loxley (1986) and Andersen, Hansen and Markussen (2006) for anecdotal evidence.
} 
likely to participate in IMF programs - presumably as the IMF loan acts as a reward. ${ }^{4}$ Note that an IMF "program" or "arrangement" is supposed to provide a loan to a country facing some form of balance of payments problem or shortage in foreign reserves, usually due to foreign debt or trade imbalances. So that the loan does not end up subsidizing bad policies that may have contributed to the economic crisis, the IMF typically conditions its loans on policy changes and economic reforms that the government must undertake. Policy conditions typically entail fiscal austerity, tight monetary policy, structural reforms, and sometimes currency devaluations. The IMF does not provide the entire loan upfront. Continued disbursements of the loan are supposed to depend on compliance with the agreed upon policy changes - an arrangement that has come to be known as "conditionality."

Yet, Stone $(2002,2004)$ shows that governments receiving more US foreign aid receive lighter punishments for noncompliance with policy conditions under IMF programs. He concludes, "Although the United States holds a minority of votes, it does indeed call the shots at the IMF, as critics allege" (2002: 62). Analyzing formal and informal power structures, and the financing needs of the Fund, Woods (2003) clearly documents that the US virtually controls major decisions at the IMF; Fratianni and Pattison (2005) summarize evidence showing that the G7 are in full control of the IMF on the big issues and that staff autonomy is restricted to areas which are of marginal interest to its shareholders. The recent empirical literature on political influences on the IMF clearly shows that developing countries get better terms from the IMF when they have closer ties with the US, as measured by their voting behavior in the UN General Assembly (Barro and Lee 2005, Vreeland 2005, Dreher and Jensen 2007). Faini and Grilli (2004) report that IMF lending is influenced by the US and EU. ${ }^{5}$ In the words of Rieffel (2003: 28-29), "The IMF is an instrument of the G-7 countries. There is no example that comes easily to mind of a position taken by the IMF on any systematic issue

\footnotetext{
4 Thacker defines "key votes" following the direct announcements of the US State Department, which publishes the list of UN votes that it considers important in its annual report to Congress.

${ }_{5}^{5}$ Research also shows that developing countries heavily indebted to US banks receive larger loans. See Oatley and Yackee (2004) and Broz and Hawes (2006).
} 
without the tacit, if not explicit, support of the United States and the other G-7 countries." 6

Overall, there is reason to believe that foreign aid is not only given to help countries in economic distress but also to achieve the donor's political objectives. In fact, since the late 1940s every US administration considered foreign aid to be important in achieving foreign policy goals (Ruttan 1996). It has even been claimed that the primary purpose of US economic assistance is in promoting overall US policy objectives (Zimmerman 1993). According to Morgenthau (1962: 302), "the transfer of money and services from one government to another performs here the function of a price paid for political services rendered or to be rendered."

In this paper, we seek to investigate whether the IMF's major stakeholders use their power in the Fund to make it give better treatment to countries on the UN Security Council. To the extent that the Fund's major stakeholders care about voting on the UN Security Council, and to the extent that they can influence the IMF to reward countries that they favor, we expect to find a relationship between participation in IMF programs and membership on the UN Security Council.

To anticipate our results, we find that temporary Security Council membership increases the probability of receiving IMF programs by about 20 percent. The qualitative results are robust to the inclusion of economic and political factors, as well as regional, country, and year specific effects.

We continue as follows. The next section provides some background on the UNSC and the IMF, while section three develops our hypothesis. The fourth section describes the data and method of estimation; in the fifth section we present the results of our analysis, while we discuss extensions in section six. Section seven concludes.

\section{The UNSC and the IMF}

The Security Council is the primary organ of the United Nations with responsibility for the maintenance of international peace and security. Its duties include taking military

\footnotetext{
${ }^{6}$ For example, a report for the US House of Foreign Affairs Committee concludes that the United States prevents for political reasons certain countries from borrowing IMF money, and that other nations exert their influence in a similar (but less rigorous) manner (Kwitny 1983). For case studies of US influence, see Momani (2004a, b).
} 
action against aggressors and investigating disputes or situations likely to lead to international frictions. The Security Council has the power to make binding resolutions and may adopt legally binding measures in order to maintain or restore international peace - including the use of armed forces.

Ten of the fifteen seats on the UN Security Council are held by temporary members, while five members - China, France, Russia, the United Kingdom, and the United States - serve on a permanent basis. Each year, five temporary members are elected for a two-year term. They are nominated by their regional caucus and have to be approved by at least two thirds of the votes in the General Assembly. Since 1966, the composition of the 10 temporary members has been: 3 from Africa, 2 from Latin America and the Caribbean, 2 from Asia, 1 from Eastern Europe, and 2 advanced industrial countries. ${ }^{7}$ The elections are usually held about three months before the term starts on January 1.

Each member of the UNSC has one vote. Decisions on substantive matters require a majority of nine votes. The permanent members have veto powers. Thus, for any given matter, the votes of four out of the ten temporary members are required, in addition to all five votes of the permanent members. All votes are by open ballot.

According to Kuziemko and Werker (2005), there is extensive competition for the temporary seats on the Security Council as countries might expect to receive net rewards during their tenure. Kuziemko and Werker (2005) find, for example, that average US aid increases by 54 percent and average UN development aid by 7 percent when a country is elected to the Security Council. Another possible benefit of serving on the Council is the likelihood of receiving greater support from international organizations like the IMF.

\footnotetext{
${ }^{7}$ Before 1966, there were only 6 elected members of the UNSC. Composition was typically: 2 from Latin America, 1 from the Middle East, 1 from Eastern Europe, and 2 advanced industrial. As more countries entered the UN, this composition sometimes was altered in an effort to improve representation. Yugoslavia and Philippines shared a term in 1956-7, Poland and Liberia shared a term in 1960-1, Turkey and Ireland shared a term in 1961-2, Romania and Philippines shared a term in 1962-3, and Czechoslovakia and Malaysia shared a term in 1964-5. Finally, membership was simply expanded to accommodate the newly independent countries of Africa and Asia. Note that our analysis is not affected by the expansion of the UNSC from six to ten non-permanent members at a time when being under an IMF program also became more likely, as most of our results refer to a later period. In those cases our analysis covers the years before the enlargement also, our results do not qualitatively change when we restrict the period under study to the years after 1966. For more history of the UNSC, see Russett (1997).
} 
Eldar (2004) provides anecdotal evidence. As one example, the US promised China to support its loan request from the World Bank in exchange for support of a convention regarding deployment of armed forces in Iraq in the Security Council in 1991. Another example Eldar (2004) points to is the 1994 UNSC resolution on the restoration of democracy in Haiti. The US helped China to obtain World Bank loans (and gave China security guarantees regarding Taiwan), eventually leading to China's abstention from the vote.

Turning to examples of elected members of the UNSC, consider the experience of Tanzania. Following independence in 1961, the government did not enter into an IMF arrangement for a decade and a half. Then Tanzania ran for election to the UNSC in the fall of 1974. That year it received an IMF loan of 6.3 million $\mathrm{SDR}^{8}$ with no policy conditions attached. ${ }^{9}$ The government received another unconditional IMF loan for 3.15 million SDR in 1975. ${ }^{10}$ Tanzania then entered into a one year Stand-by Arrangement for 10.5 million SDR on 21 August 1975 (IMF Survey 1975: 254). ${ }^{11}$ The policy conditions associated with this arrangement were notably weak. The IMF merely requested that domestic credit usage by the public sector be constrained (Stein 1992: 63). Tanzanian President Julius Nyerere used his high international profile and his country's first seat on the UNSC to negotiate for IMF loans and soft conditionality, and by the end of 1975, Tanzania appeared to have very positive relations with the IMF.

What is particularly interesting about this case is that Tanzania voted along with the United States, Japan, the United Kingdom and France - the members of the UNSC who had the most influence at the IMF - on every UNSC resolution passed in $1975 .{ }^{12}$ Early in 1976, however, after already having received nearly 10 million SDR in loans already from the IMF, the Tanzanian government decided to vote for some resolutions that were not supported by all of the powerful members of the IMF. In March, Tanzania

\footnotetext{
${ }^{8}$ SDR stands for "Special Drawing Rights," a fictitious currency used by the IMF for accounting purposes. The value of the SDR is determined by a basket of "hard" or especially stable currencies: the American dollar, the German mark, the Japanese yen, the British pound, and the French franc (the euro has come to replace the mark and the franc). By pegging the value of the SDR to this basket of currencies, the SDR is more stable than any of its component parts. One unit of SDR tends to be valued at around \$1.25-\$1.50.

${ }^{9}$ The loan came from the IMF Oil Fund Facility, a special facility that involved virtually no conditionality (IMF Survey 1974: 86).

${ }^{10}$ This loan was also from the Oil Fund Facility (IMF Survey 1975: 77).

11 "Stand-by Arrangements" are the oldest and most common form of IMF conditioned arrangement.

${ }^{12}$ Security Council resolutions 367-386.
} 
voted for a resolution condemning US Cold War ally South Africa's aggression against Angola. The US, Japan, the United Kingdom, France, and Italy abstained from this resolution. In April, Tanzania voted for a resolution calling for Indonesia to withdraw from East Timor; the US and Japan abstained. And in July, Tanzania voted for a resolution condemning South Africa's attack of Zambia; the US abstained. Interestingly, the IMF never disbursed the Stand-by Arrangement loan that had been signed in August 1975

Further anecdotes abound: Gabon achieved independence in 1960 and never entered into and IMF arrangement until 31 May 1978, about 5 months after joining the UNSC for the first time. During its tenure as a UNSC member, it voted on several important resolutions, siding with the US, France, Germany, and Canada - and against the Soviet Union - on issues such as a UN Interim Force set up in Lebanon and Namibian independence. Gabon did support some resolutions condemning South Africa where the US, UK, France, Germany, and Canada abstained. The IMF disbursed exactly half of the agreed upon 15 million SDR loan to Gabon.

Zimbabwe entered into its first IMF arrangement on March 8, 1981 for 37.5 million SDR. Then it served on the UNSC in 1983-4, and it entered into its second IMF arrangement on March 23, 1983 for 300 million SDR of which 175 million was actually disbursed. The size of the loan was an order of magnitude higher! Zimbabwe voted along with the US on important Middle East resolutions, but did support resolutions against South Africa for which the US abstained.

Zimbabwe participated in no further IMF agreements for nearly a decade, which is atypical for a developing country. It finally signed another IMF arrangement in 1992, coincident with its 1991-2 term on the UNSC. This time, the IMF loan was for 343 million SDR, of which over $90 \%$ was disbursed by the IMF. During this stint as a UNSC member, Zimbabwe voted on several resolutions regarding Iraq that the US cared a great deal about, including some resolutions that did not receive support from other developing countries. For example, Zimbabwe supported Security Council resolution 686 (March 2, 1991), demanding that Iraq rescind its actions purporting to annex Kuwait, which Cuba voted against, and China, India, and Yemen abstained. It also supported a further Security Council resolution 687, also regarding Iraq's actions in Kuwait, which Cuba voted 
against, and Ecuador and Yemen abstained. Zimbabwe failed to support resolution 688 on Iraq, along with Cuba and Yemen, with China and India abstaining. But after being threatened with new IMF conditions for failing to vote on resolutions legitimizing the attack on Iraq (Pilgar 2002), Zimbabwe subsequently supported Security Council resolutions 689, 692, 700, 706, 773, 778 on Iraq and Kuwait, and resolutions 699, 705, 707, 712, 715 condemning Iraq.

Romania also served around the time of the Gulf War, 1990-1. The government signed an IMF arrangement April 11, 1991 for 380.5 million SDR, of which 318.1 million SDR was actually disbursed by the IMF. Why such generous treatment? Consider its voting record on resolutions pertaining to Iraq and Iraq's involvement in Kuwait. Romania voted in favor of every US-supported resolution. ${ }^{13}$

Like Zimbabwe and Romania, Ecuador was a member of the UNSC around the time of the Gulf War (1991-2). The government of Ecuador signed an IMF arrangement 11 December 1991, and ended up receiving nearly 20 million SDR from the IMF. How did Ecuador vote on the UNSC with respect to Iraq? While abstaining on Security Council resolutions 687 and 773, it voted for resolutions 686, 688, 689, 692, 699, 700, $705,706,707,712,715$, and 778 .

The one member of the UNSC that most consistently opposed the US resolutions over the Gulf War was Cuba, who was a UNSC member 1990-1. Note that Cuba had nothing to lose with respect to the IMF. Cuba ceased to be a member of the IMF in 1964, claiming the IMF was a tool of the US and Western Capitalism. Today, Cuba is one of a small handful of countries that do not belong to the IMF and cannot receive loans from the institution as a consequence. Surprisingly, however, the early history of Cuba provides yet another anecdote in favor of our argument. Cuba first served on the UNSC 1949-50, before IMF arrangements existed. Then it served again on the UNSC 1956-7, and it entered its first and only IMF arrangement on December 7, 1956 for a loan of 12.5 million SDR.

Much of the above anecdotal evidence may be circumstantial, yet there is a good deal of evidence that G7 countries, and the US in particular, place substantial weight on

\footnotetext{
${ }^{13}$ That is, Security Council resolutions 660, 661, 662, 664, 665, 666, 667, 669, 670, 674, 677, 678, 686, $687,688,689,692,699,700,705,706,707,712$, and 715 .
} 
UN decision making and are willing to use their influence to pressure and reward countries to vote their way. Bennis (1997) claims that "US influence in (and often control of) the UN comes in the form of coercing the organization to take one or another position, or to reject some other position, or pressuring a country or countries to vote a certain way in the General Assembly."

According to Eldar (2004), the US heavily pressured temporary members of the UNSC to get support for a resolution implying military intervention in Iraq 1991, including "a promise of financial help to Columbia, Côte d'Ivoire, Ethiopia and Zaire; a promise to the USSR to keep Estonia, Latvia and Lithuania out of the Nov 1990 Paris Summit conference and to persuade Kuwait and Saudi Arabia to provide it with hard currency..." Before the second Gulf War, the US attempted to buy votes of temporary UNSC members to pass a resolution on the use of armed forces in Iraq (Eldar 2004). Overall, there is strong reason to expect vote-buying to be prevalent in a substantial proportion of UNSC decisions (Eldar 2004).

There is also plenty of evidence that the IMF has been used to bribe or reward countries for voting inline with major G7 countries in the UN General Assembly. Thacker (1999) shows that conclusion of IMF programs depends on countries' voting behavior in the Assembly. He employs two variables - one indicating a country's political agreement with the US, the other reflecting movement in political alignment. According to his results for the period 1985-94, political proximity has no statistically significant impact when serial correlation is taken into account. However, a movement to the US significantly increases the probability of receiving an IMF program. The results also show that the impact of a movement towards the US on the probability to obtain IMF programs does not depend on the initial position. A movement towards the US position is correlated with IMF involvement regardless of the initial political stance of the recipient country. Interestingly, a country starting at a point very distant from the US has a much better chance of receiving a program when moving towards the US position than a country that is closely allied with the US, but slightly moves away from it. ${ }^{14}$

\footnotetext{
${ }^{14}$ Similarly, Alesina and Dollar (2000) analyze the impact of voting on bilateral aid. Results from their panel analysis show that countries voting with Japan receive more bilateral aid, while voting with the US has no impact when controlled for US interests in the Middle East. Voting with other major donor countries has no impact. Other papers examining the impact of voting in the UN General Assembly on bilateral aid
} 
Oatley and Yackee (2004) show for the period 1985-1998 that the IMF offers larger loans to closer US allies, as measured by UN voting patterns. However, this result is not completely robust to the underlying specification. Barro and Lee (2005) employ averages for the voting behavior of France, Germany and the UK, and an individual variable for the US. As it turns out, only voting with the European countries significantly increases the amount of IMF loans disbursed over the period 1975-2000. According to Stone (2004) who analyzed monthly data on 53 African countries for 1990-2000, enforcement of IMF conditionality depends on US foreign aid, membership in postcolonial international institutions, and UN General Assembly voting in line with France. Dreher and Jensen (2007) find for a sample of 206 letters of intent over the period 19972003 that the number of conditions on an IMF loan depends on a borrowing country's voting pattern in the UN General Assembly. Closer allies of the G7 receive IMF loans with fewer conditions. Dreher and Sturm (2006) show that IMF and World Bank lending influences voting in the UN General Assembly. According to their panel study, countries receiving non-concessional IMF programs vote more frequently in line with the average G7 country.

\section{The Hypothesis}

As outlined above, Kuziemko and Werker (2005) show that a country's US aid increases substantially while temporarily sitting on the UNSC. They conclude that in providing extra aid to temporary UNSC members, aid donors implicitly revealed they put some faith in the relevance of Security Council's votes. This even holds when the outcome of the vote is obvious a priori. It is well established in the vote-buying literature that oversized coalitions tend to be established (see, e.g., Volden and Carrubba, 2004). Given that the UNSC matters mostly for reasons of legitimacy, there is a premium for getting (near) unanimous votes (see, e.g., Doyle 2001: 223). For example, it is well known that the US threatened Yemen with dire consequences (which materialized) if it did not vote in favor for resolution 678, on the use of armed forces against Iraq in 1990, even though Yemen's

include Ball and Johnson (1996), Boschini and Olofsgard (forthcoming), Alesina and Weder (2002), and Fleck and Kilby (2006). Kilby (2006) employs UN voting patterns in his analysis of donor influence on the Asian Development Bank. For early analysis of donor influence in the World Bank, see Schneider et al. (1985) and Frey and Schneider (1986). 
vote was in no way pivotal (e.g. Pilger, 2002). As another example, consider the run up to the recent war in Iraq where President Bush was going to take the vote to the UNSC even though he knew the French were going to veto. He was lobbying some of the nonpermanent members with aid packages in an attempt to win a simple majority in the Council. This makes no sense in terms of the UNSC's institutional rules but it might have provided some legitimacy to the war for the US audience.

Because of their power at the IMF, the G7 can use the Fund to influence recipient countries' behavior in line with their interests. Possible channels for US influence on the IMF have been discussed in detail in Broz and Hawes (2006). They argue that the US Congress is influenced by lobbies with stakes in IMF policy. Congress, in turn, commands the allegiance of US officials at the IMF. As the results of their empirical analysis show, a congressperson is more likely to vote in favor of an IMF quota increase, the higher have been campaign contributions from big US banks and the greater the proportion of winners from the IMF's pro-globalization mandate in its district. ${ }^{15}$

The benefits for the $\mathrm{G} 7$ of bribing or rewarding other governments indirectly via the Fund instead of directly with their own aid programs might be substantial. It has been argued that national governments delegate unpleasant tasks they consider necessary to gain the support of interest groups to international organizations ("dirty work"). This might allow governments to escape the nationalist resentment those actions would create when imposing more direct pressure (Vaubel 1986, 1991, 1996). Pursuing its global interests unilaterally outside international institutions can impose substantial costs on the US. In the absence of UNSC legitimacy, domestic public support might be more difficult to achieve and US Congress might also be recalcitrant (Voeten 2001). ${ }^{16}$ Also, the US bears a smaller share of the burden and needs fewer soldiers as compared to unilateral actions (Sandler and Hartley 1999). According to Eldar (2004), votes are almost always traded behind the scenes, because most countries prefer to conceal vote trading arrangements to escape public and political condemnation. As Harrigan, Wang and ElSaid (2006) argue, the IMF can impose punishments or rewards much wider in scope

\footnotetext{
${ }^{15}$ See also Bird and Rowlands (2001).

${ }^{16}$ Voeten (2001) provides examples. He cites the memoirs of James Baker (1995: 278), emphasizing domestic support to be the main reason for the US government to seek a multilateral solution to the Gulf War. He also cites Malone (1998: ix), arguing that it was easier for the Clinton administration to secure support of the UNSC as compared to those of the US Congress.
} 
than any single donor could. Fund loans are usually much more valuable to potential borrowers than they are costly for the US (Eldar 2004). In fact, bilateral donors frequently attach their money to IMF programs, substantially increasing the Fund's leverage. Western countries might thus try to influence the Fund to reinforce the already existing bilateral pressure.

We thus hypothesize: UN Security Council membership increases the probability of receiving IMF programs.

\section{Data and Method ${ }^{17}$}

First, consider what we observe: Our dataset includes 7,606 country-year observations of 191 countries $^{18}$ from 1951 (the first year of IMF Stand-by Arrangements) to 2004. The panel is unbalanced because countries enter and leave the sample in different years, but there are no missing data - this includes all independent countries for the time period, following Cheibub and Gandhi's (2004) reckoning, minus the observations for the five permanent members of the UNSC. ${ }^{19}$

Our dependent variable is IMF participation, a dummy variable coded 1 if a country participates in an IMF program during part of the year and 0 otherwise. ${ }^{20}$ Our principal explanatory variable of interest is UNSC membership, a dummy variable coded 1 if a country is temporarily serving on the UNSC, and 0 otherwise. Membership begins on January 1 of the year and lasts two years, although there are some rare cases where service lasted only one year. Governments participated in IMF programs in 2,028 of the 7,606 observations (26.7 percent), and they served as temporary members of the UN Security Council in 477 observations (6.3 percent). Serving on the UN Security Council

\footnotetext{
${ }^{17}$ Appendix B summarizes the sources and definitions of the variables we use, while descriptive statistics are reported in Appendix $\mathrm{C}$ and $\mathrm{D}$.

${ }^{18}$ Some countries, like the Yemen Arab Republic, no longer exist.

${ }^{19}$ Following Cheibub and Gandhi (2004), we do not include Ukraine or Belarus before 1991, as they are not generally considered to have been independent countries. However, they were separate members of the UN and even served as UNSC members in 1948-9, 1984-5 (Ukraine), and 1974-5 (Belarus). As they were not members of the IMF at this time, however, they should perhaps not be included in the sample. Certainly they cannot be included in analyses that control for economic determinants of IMF participation because there are no reliable economic data on these countries before 1991.

${ }^{20}$ We restrict our attention to participation in conditional IMF arrangements: Stand-by, Extended Fund Facility, Structural Adjustment Facility, and Extended Structural Adjustment Facility/Poverty Reduction and Growth Facility. This is in line with most of the previous literature.
} 
is a relatively rare event, whereas participation in IMF programs is quite common throughout the developing world. ${ }^{21}$

As Figure 1 illustrates, governments not serving on the UN Security Council participate in IMF programs only 26.2 percent of the time, while governments serving on the UNSC participate 33.3 percent of the time. ${ }^{22}$ This increase by over 25 percent (or of more than 7 percentage points) of the baseline probability is highly significant (see Appendix C). Restricting our attention to only those observations of countries that actually serve on the UNSC, we see that participation in IMF programs is lower the years before and after service on the UNSC than it is during service. Comparing these with all remaining observations reveals that already the year after membership is no longer statistically different, in contrast to especially the years during membership (see Appendix C). In other words, the increase in IMF program participation rates does appear to be driven by UNSC membership.

What about patterns within the regional caucuses that nominate candidates for UNSC membership? Figure 2 shows that the pattern holds at varying levels of strength for every developing region in the world - Africa, Asia and the South Pacific, Latin America and the Caribbean. The differences between members and non-members of the UN Security Council are highly significant. The basic pattern holds, but is notably weak in Eastern Europe, the Middle East and North Africa, where UN Security Council votes are known to be costly to bribe or reward because of the salience of issues involving Israel or alliances during the Cold War. It may not be worth the effort of powerful countries to push the IMF to assist these countries, especially where IMF loans will have little impact in countries rich in oil and foreign reserves. The pattern does not hold for industrialized nations, which ceased to participate in IMF programs in the 1970s, and in the 1950 s were more likely to be influenced by Marshall Plan aid than by IMF loans. ${ }^{23}$

\footnotetext{
${ }^{21}$ One possibility that comes immediately to mind is the selection problem: If selection onto the UNSC is non-random, could some outside factor cause both UNSC membership and IMF participation? We return to this below.

${ }^{22}$ The horizontal line in Figure 1 and all following figures shows the average IMF participation rate across our entire sample.

${ }^{23}$ See Eichengreen (1998: 105 fn 23, 108).
} 


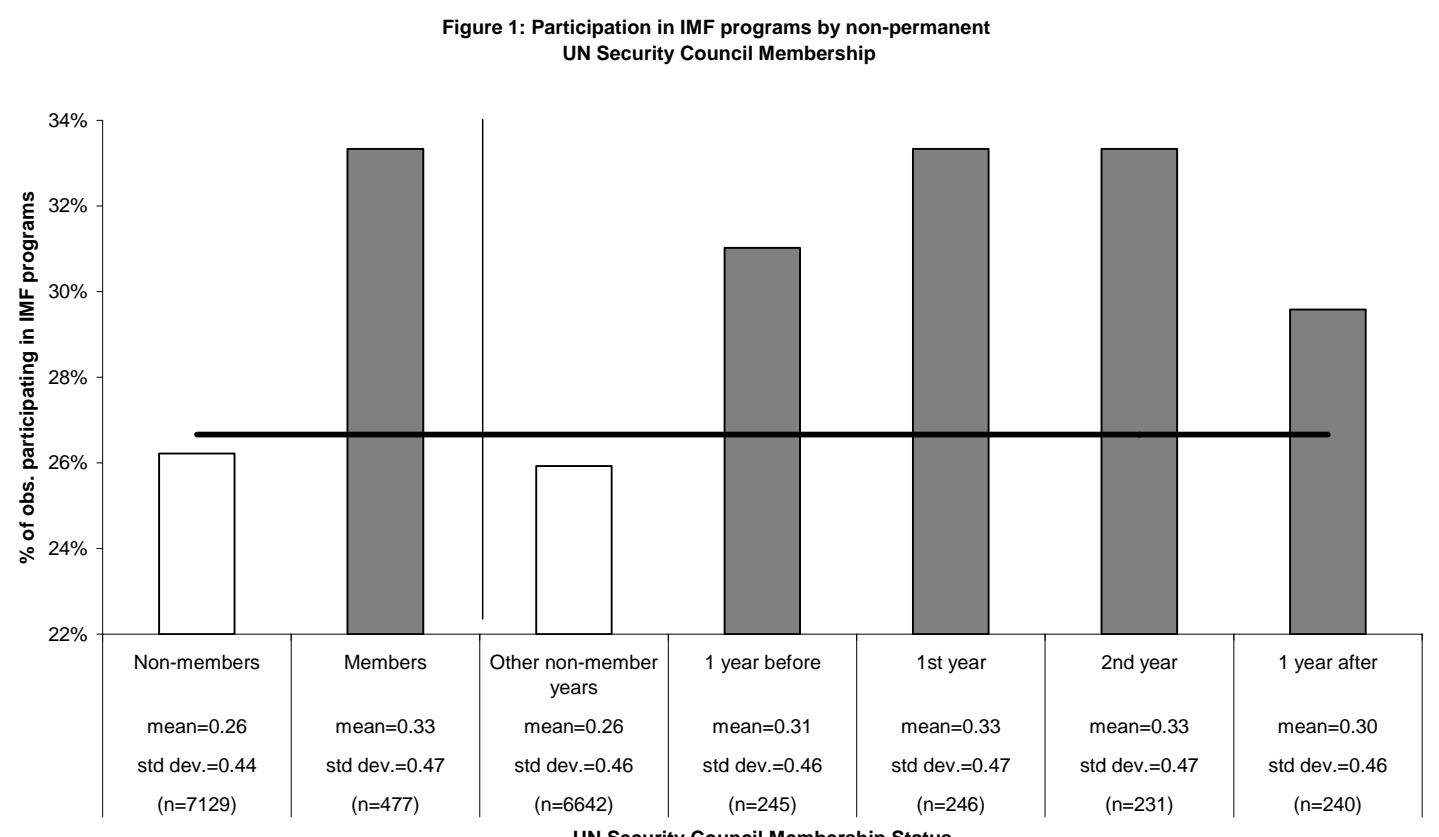

Figure 2: Participation in IMF programs by UN Security Council Membership across regions and during the Cold War

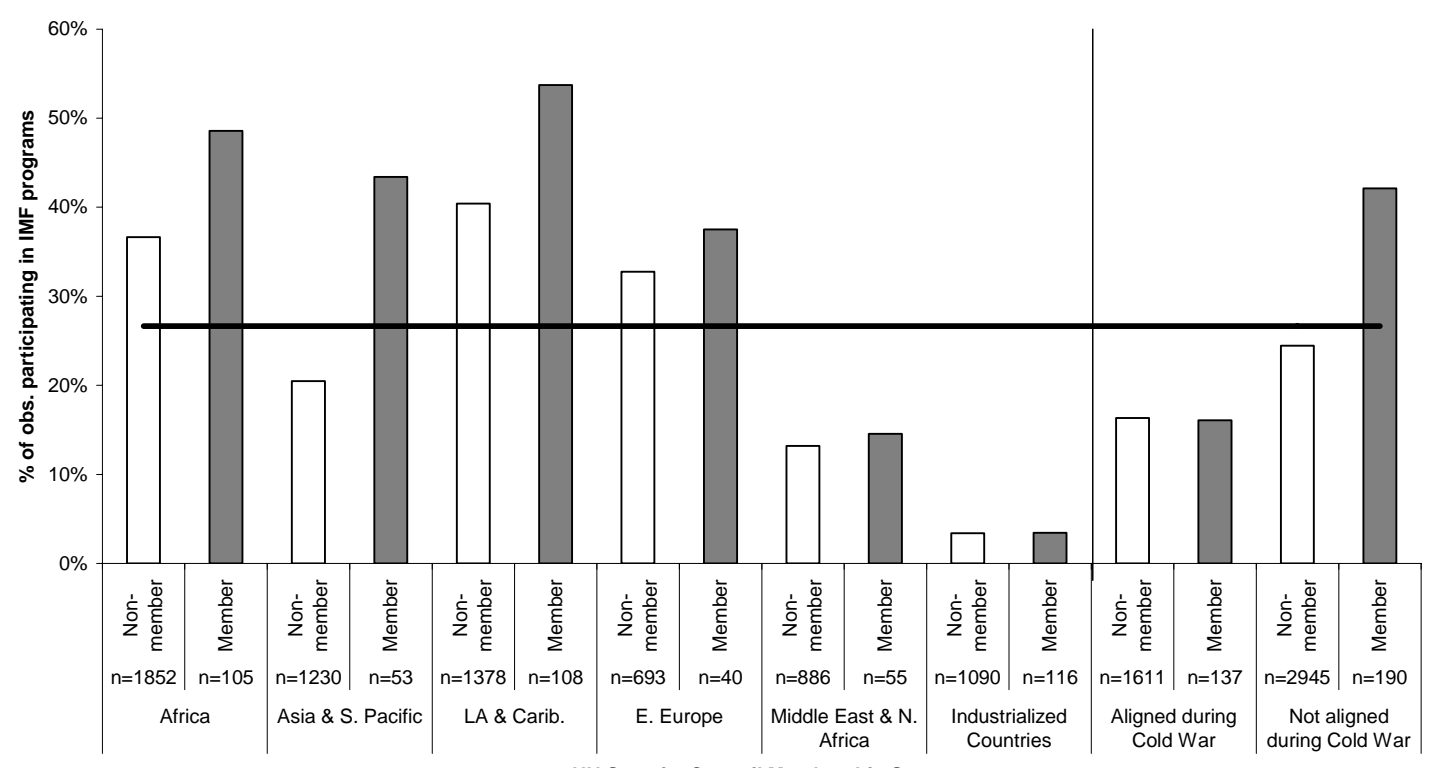

UN Security Council Membership Status

The graph also shows that there is no difference in the number of IMF programs when countries of the Western or Eastern block enter the Security Council in the years prior to 
1991. ${ }^{24}$ This makes sense. As those countries are very unlikely to vote against "their" block anyway, it is also unlikely that they are bribed or rewarded with IMF programs. We return to this below.

Does this pattern hold when put to more rigorous tests? To explore this, we analyze various statistical models with IMF program participation as our dependent variable and UN Security Council Membership as principal explanatory variable of interest. First, we employ a simple logit model to test the significance of the bivariate relationship. Next, we introduce fixed country or regional effects. In the latter case, we can also control for fixed effects for years. ${ }^{25}$

Taking time more seriously, we also control for possible duration dependence. IMF programs are notorious for their longevity, with consecutive IMF arrangements spanning decades in many countries. ${ }^{26}$ We want to ensure that our findings do not result due to time trends in the data. Thus, we employ Beck, Katz, and Tucker's (1998) remedy to test and correct for temporal dependence, using a count-variable and three temporal splines. The splines, along with a count variable for the number of years a country is observed not participating, approximates a Cox regression, which allows for nonparametric estimation of duration dependence. The approach is equivalent to including a series of dummy variables that "count" the number of years of non-participation in IMF programs. Thus, there is a dummy variable coded 1 for country-years not participating for exactly one year and 0 otherwise; another dummy coded 1 for country-years not

\footnotetext{
${ }^{24}$ Our group on "non-aligned" countries contains the 113 UN members of the so-called "Non-Aligned Movement (NAM)."

${ }^{25}$ Because our dependent variable is dichotomous, we employ conditional logit to control for fixed effects, following Green et al. (2001). The model, developed by Chamberlain (1980), is sometimes called "the conditional logit model" because one maximizes the conditional likelihood function: $L\left(\beta \mid d_{i t}, x_{i t}\right)=\prod_{i} \operatorname{Pr}\left(D_{i 1}=d_{i 1}, D_{i 2}=d_{i 2}, \ldots, D_{i T_{i}}=d_{i T_{i}} \mid \sum_{t} d_{i t}\right)$, where $T_{i}$ is the last observed time for individual $i$ (country or year, for example). Note that this method involves estimating the 1's and 0's for a particular country, conditioned on the total number of 1's for that country. If a country never reports data or reports data all of the time, the conditional probability of observing the data for that country is 1 . Such countries have no impact on the overall estimation and are thus dropped from the analysis. Further note that this model does not allow one to control for fixed country and year effects simultaneously because our data are arranged in country-year format and the conditional probability of each observation would be 1 .

${ }^{26}$ Even though Stand-by Arrangements are intended to last about 18 months and other IMF programs are intended to last no more than four years, the typical pattern of participation is five years under, five years out, then five years under again. There are many outliers with more extreme patterns of participation (see Vreeland 2006).
} 
participating for exactly two years and 0 otherwise, another for 3 years of nonparticipation, etc. Note that with a long time-series like ours, the dummy variable approach would entail over 50 additional variables. The splines serve to approximate the same controls with fewer variables by essentially grouping similar types of observations. We follow Beck et al. (1998), who suggest three splines to be sufficient. While this method is ubiquitous in political science with typically no explanation or inclusion of coefficients, we present them. Duration dependence is strong in our data. Countries are likely to return to the IMF shortly after participation ends. If a country does not return right away, the likelihood first increases but eventually attenuates. This is consistent with the IMF literature on so-called "recidivism." ${ }^{, 27}$ For more details on the method, we refer readers to Beck et al. (1998).

Following the bivariate analysis of the relationship between UNSC membership and IMF participation, we then introduce different control variables to ensure that our results are not spurious and repeat for each specification the five statistical models - (1) pooled logit, (2) conditional logit to control for country fixed effects (Chamberlain 1980), (3) logit with regional dummy variables, (4) conditional logit to control for year fixed effects with regional dummies, and (5) fixed effects logit controlling for duration dependence with temporal splines.

We begin by including the most robust predictors of IMF participation following the Extreme Bounds Analysis (EBA) of Sturm, Berger and de Haan (2005). Then we introduce additional control variables which have been identified in the literature as important, although they do not reliably predict IMF participation. Next, we analyze a "stripped" specification, which includes only variables for which there are ample data. Many important control variables suffer from a great deal of missing data - some of the samples analyzed in the above mentioned models cover only about 1,000 observations, out of the original 7,606 observations with which we began our analysis. The "large sample" specification allows us to test the generality of our findings while still controlling for at least those variables that have reasonable data coverage (leaving us with

\footnotetext{
${ }^{27}$ See, for example, Bird (1996), Przeworski and Vreeland (2000), Vreeland (2003), and Bird, Hussain, and Joyce (2004).
} 
about 4,500 observations with the fixed effects models and about 5,500 observations for the other models). ${ }^{28}$ The next section presents our results.

\begin{tabular}{|c|c|c|c|c|c|}
\hline & Pooled Logit & $\begin{array}{c}\text { Conditional Logit } \\
\text { (Country Fixed } \\
\text { Effects) }\end{array}$ & $\begin{array}{c}\text { Pooled Logit with } \\
\text { Regional Fixed } \\
\text { Effects }\end{array}$ & $\begin{array}{c}\text { Conditional Logit } \\
\text { (Year Fixed Effects) }\end{array}$ & $\begin{array}{c}\text { Conditional Logit } \\
\text { with Temporal } \\
\text { Splines } \\
\end{array}$ \\
\hline UNSC & $\begin{array}{l}\mathbf{0 . 3 4} 4^{\star *} \\
(0.10)\end{array}$ & $\begin{array}{l}\mathbf{0 . 2 4} 4^{\star \star} \\
(0.12)\end{array}$ & $\begin{array}{l}\mathbf{0 . 5 0} \\
(0.11)\end{array}$ & $\begin{array}{l}\mathbf{0 . 5 7} \\
(0.10)\end{array}$ & $\begin{array}{l}\mathbf{0 . 3 0 * *} \\
(0.15)\end{array}$ \\
\hline Africa & & & $\begin{array}{l}0.19 * \star \\
(0.09)\end{array}$ & $\begin{array}{c}0.18 \\
(0.13)\end{array}$ & \\
\hline Asia & & & $\begin{array}{c}-0.59 * * \\
(0.10)\end{array}$ & $\begin{array}{c}-0.55^{\star \star} \\
(0.15)\end{array}$ & \\
\hline Middle East/ North Africa & & & $\begin{array}{c}-1.17^{\star \star} \\
(0.12)\end{array}$ & $\begin{array}{c}-1.10^{\star \star} \\
(0.16)\end{array}$ & \\
\hline Latin America /Caribbean & & & $\begin{array}{l}0.35^{\star \star} \\
(0.09)\end{array}$ & $\begin{array}{l}0.47^{\star *} \\
(0.19)\end{array}$ & \\
\hline \multicolumn{6}{|l|}{ Eastern Europe } \\
\hline Industrialized Countries & & & $\begin{array}{c}-2.67^{\star \star} \\
(0.18)\end{array}$ & $\begin{array}{c}-2.59 \text { ** } \\
(0.29)\end{array}$ & \\
\hline Non-Participation Years & & & & & $\begin{array}{l}-0.84^{\star *} \\
(0.03)\end{array}$ \\
\hline Spline 1 & & & & & $\begin{array}{l}-0.0004^{\star *} \\
(0.0001)\end{array}$ \\
\hline Spline 2 & & & & & $\begin{array}{c}-0.01^{\star *} \\
(0.0005)\end{array}$ \\
\hline Spline 3 & & & & & $\begin{array}{c}0.004^{\star \star} \\
(0.0003)\end{array}$ \\
\hline Constant & $\begin{array}{c}-1.03^{\star \star} \\
(0.03)\end{array}$ & & $\begin{array}{c}-0.74^{\star *} \\
(0.08)\end{array}$ & & \\
\hline \# of obs. & 7,606 & 5,694 & 7,606 & 7,532 & 5,694 \\
\hline \# of countries & 193 & 137 & 193 & 182 & 137 \\
\hline Log pseudolikelihood & -4405.02 & -2877.41 & -3969.74 & -3669.54 & -2040.09 \\
\hline
\end{tabular}

Robust standard errors are in parentheses; ** indicates significance at the $5 \%$ level; and * indicates significance at the $10 \%$ level.

\footnotetext{
${ }^{28}$ The difference in the number of observations is because countries observed with the same value for the dependent variable (either always or never participating in IMF programs), as noted above, are essentially dropped from the analysis using the fixed effects or "conditional" logit model.
} 
Table 2: Controlling for Robust Predictors of IMF Participation

\begin{tabular}{|c|c|c|c|c|c|}
\hline & Pooled Logit & $\begin{array}{c}\text { Conditional Logit } \\
\text { (Country Fixed } \\
\text { Effects) }\end{array}$ & $\begin{array}{l}\text { Pooled Logit with } \\
\text { Regional Fixed } \\
\text { Effects }\end{array}$ & $\begin{array}{l}\text { Conditional Logit } \\
\text { (Year Fixed Effects) }\end{array}$ & $\begin{array}{l}\text { Conditional Logit } \\
\text { with Temporal } \\
\text { Splines }\end{array}$ \\
\hline UNSC & $\begin{array}{l}\mathbf{0 . 4 5} 5^{\star *} \\
(0.21)\end{array}$ & $\begin{array}{l}\mathbf{0 . 5 7} 7^{\star \star} \\
(0.23)\end{array}$ & $\begin{array}{l}\text { 0.41* } \\
(0.22)\end{array}$ & $\begin{array}{l}\mathbf{0 . 4 4} 4^{\star *} \\
(0.21)\end{array}$ & $\begin{array}{l}\mathbf{0 . 4 8}^{\star \star *} \\
(0.24)\end{array}$ \\
\hline Foreign Reserves & $\begin{array}{l}-0.14^{\star \star} \\
(0.02)\end{array}$ & $\begin{array}{l}-0.01 \\
(0.07)\end{array}$ & $\begin{array}{l}-0.11^{\star *} \\
(0.02)\end{array}$ & $\begin{array}{c}-0.12^{\star *} \\
(0.03)\end{array}$ & $\begin{array}{l}-0.03 \\
(0.06)\end{array}$ \\
\hline Debt Service & $\begin{array}{c}0.02^{\star \star} \\
(0.004)\end{array}$ & $\begin{array}{l}0.02^{\star *} \\
(0.01)\end{array}$ & $\begin{array}{c}0.02^{\star \star} \\
(0.004)\end{array}$ & $\begin{array}{l}0.02^{\star \star} \\
(0.01)\end{array}$ & $\begin{array}{l}0.02^{\star *} \\
(0.01)\end{array}$ \\
\hline Investment & $\begin{array}{c}-0.05^{\star *} \\
(0.01)\end{array}$ & $\begin{array}{c}-0.06^{\star \star} \\
(0.02)\end{array}$ & $\begin{array}{c}-0.05^{\star *} \\
(0.01)\end{array}$ & $\begin{array}{l}-0.05^{\star \star} \\
(0.01)\end{array}$ & $\begin{array}{c}-0.04^{\star \star} \\
(0.02)\end{array}$ \\
\hline Past Participation & $\begin{array}{l}2.56^{\star \star} \\
(0.18)\end{array}$ & $\begin{array}{l}2.73^{\star \star} \\
(0.33)\end{array}$ & $\begin{array}{l}2.71^{\star \star} \\
(0.19)\end{array}$ & $\begin{array}{l}2.54^{\star \star} \\
(0.23)\end{array}$ & $\begin{array}{c}1.03 \\
(0.72)\end{array}$ \\
\hline Lagged Election & $\begin{array}{c}0.15 \\
(0.13)\end{array}$ & $\begin{array}{c}0.14 \\
(0.14)\end{array}$ & $\begin{array}{c}0.12 \\
(0.13)\end{array}$ & $\begin{array}{c}0.07 \\
(0.13)\end{array}$ & $\begin{array}{c}0.20 \\
(0.19)\end{array}$ \\
\hline Africa & & & $\begin{array}{c}-1.40^{\star *} \\
(0.31)\end{array}$ & $\begin{array}{c}-1.29 * \star \\
(0.43)\end{array}$ & \\
\hline Asia & & & $\begin{array}{c}-1.90^{\star *} \\
(0.33)\end{array}$ & $\begin{array}{l}-1.76^{\star \star} \\
(0.37)\end{array}$ & \\
\hline Middle East/ North Africa & & & $\begin{array}{c}-2.18^{\star *} \\
(0.35)\end{array}$ & $\begin{array}{c}-2.03^{\star \star} \\
(0.38)\end{array}$ & \\
\hline Latin America /Caribbean & & & $\begin{array}{c}-2.03^{\star *} \\
(0.31)\end{array}$ & $\begin{array}{l}-1.88^{\star *} \\
(0.38)\end{array}$ & \\
\hline \multicolumn{6}{|l|}{ Eastern Europe } \\
\hline \multicolumn{6}{|l|}{ Indust. Countries } \\
\hline Non-Partic. Years & & & & & $\begin{array}{c}-0.69^{\star \star} \\
(0.05)\end{array}$ \\
\hline Spline 1 & & & & & $\begin{array}{l}-0.0003^{*} \\
(0.0002)\end{array}$ \\
\hline Spline 2 & & & & & $\begin{array}{l}-0.01^{* *} \\
(0.001)\end{array}$ \\
\hline Spline 3 & & & & & $\begin{array}{l}0.004^{\star \star} \\
(0.001)\end{array}$ \\
\hline Constant & $\begin{array}{c}-1.41^{* *} \\
(0.20)\end{array}$ & & $\begin{array}{l}-0.09 \\
(0.36)\end{array}$ & & \\
\hline \# of obs. & 1,839 & 1,570 & 1,839 & 1,839 & 1,570 \\
\hline \# of countries & 118 & 82 & 118 & 118 & 82 \\
\hline Log pseudolikelihood & -1033.73 & -670.29 & -992.41 & -917.13 & -564.20 \\
\hline
\end{tabular}

Robust standard errors are in parentheses; ** indicates significance at the $5 \%$ level; and * indicates significance at the $10 \%$ level. 
Table 3: Controlling for Additional Predictors of IMF Participation

\begin{tabular}{|c|c|c|c|c|c|}
\hline & Pooled Logit & $\begin{array}{l}\text { Conditional Logit } \\
\text { (Country Fixed } \\
\text { Effects) }\end{array}$ & $\begin{array}{l}\text { Pooled Logit with } \\
\text { Regional Fixed } \\
\text { Effects }\end{array}$ & $\begin{array}{c}\text { Conditional Logit } \\
\text { (Year Fixed Effects) }\end{array}$ & $\begin{array}{l}\text { Conditional Logit } \\
\text { with Temporal } \\
\text { Splines }\end{array}$ \\
\hline UNSC & $\begin{array}{c}\mathbf{0 . 5 9 * *} \\
(0.24)\end{array}$ & $\begin{array}{c}\mathbf{0 . 8 3}^{\star *} \\
(0.29)\end{array}$ & $\begin{array}{c}\mathbf{0 . 5 6 * *} \\
(0.26)\end{array}$ & $\begin{array}{c}\mathbf{0 . 5 1 * *} \\
(0.22)\end{array}$ & $\begin{array}{c}\mathbf{0 . 6 4}{ }^{\star *} \\
(0.29)\end{array}$ \\
\hline Foreign Reserves & $\begin{array}{c}-0.15^{\star \star} \\
(0.03)\end{array}$ & $\begin{array}{c}-0.005 \\
(0.07)\end{array}$ & $\begin{array}{c}-0.13^{\star \star} \\
(0.03)\end{array}$ & $\begin{array}{c}-0.13^{\star \star} \\
(0.03)\end{array}$ & $\begin{array}{l}-0.04 \\
(0.08)\end{array}$ \\
\hline Debt Service & $\begin{array}{c}0.02^{\star *} \\
(0.01)\end{array}$ & $\begin{array}{l}0.02 \\
(0.01)\end{array}$ & $\begin{array}{c}0.03^{\star *} \\
(0.01)\end{array}$ & $\begin{array}{c}0.03^{\star *} \\
(0.01)\end{array}$ & $\begin{array}{c}0.02^{\star *} \\
(0.01)\end{array}$ \\
\hline Investment & $\begin{array}{c}-0.06^{\star *} \\
(0.01)\end{array}$ & $\begin{array}{c}-0.08^{*} \\
(0.05)\end{array}$ & $\begin{array}{c}-0.05^{\star \star} \\
(0.01)\end{array}$ & $\begin{array}{c}-0.04^{\star \star} \\
(0.01)\end{array}$ & $\begin{array}{l}-0.05 \\
(0.04)\end{array}$ \\
\hline Past Participation & $\begin{array}{c}2.47^{\star *} \\
(0.26)\end{array}$ & $\begin{array}{c}2.42^{\star \star} \\
(0.45)\end{array}$ & $\begin{array}{c}2.45^{\star \star} \\
(0.27)\end{array}$ & $\begin{array}{c}2.27^{\star *} \\
(0.34)\end{array}$ & $\begin{array}{l}2.00^{*} \\
(1.13)\end{array}$ \\
\hline Lagged Election & $\begin{array}{l}-0.02 \\
(0.16)\end{array}$ & $\begin{array}{l}-0.06 \\
(0.18)\end{array}$ & $\begin{array}{l}-0.07 \\
(0.16)\end{array}$ & $\begin{array}{l}-0.11 \\
(0.17)\end{array}$ & $\begin{array}{l}-0.11 \\
(0.21)\end{array}$ \\
\hline Budget Surplus & $\begin{array}{l}0.01 \\
(0.02)\end{array}$ & $\begin{array}{c}0.06^{\star *} \\
(0.03)\end{array}$ & $\begin{array}{l}0.01 \\
(0.02)\end{array}$ & $\begin{array}{c}-0.003 \\
(0.02)\end{array}$ & $\begin{array}{c}0.06^{\star *} \\
(0.03)\end{array}$ \\
\hline Inflation & $\begin{array}{c}-0.0002^{\star *} \\
(0.0001)\end{array}$ & $\begin{array}{c}-0.0003 \\
(0.0002)\end{array}$ & $\begin{array}{c}-0.0002^{*} \\
(0.0001)\end{array}$ & $\begin{array}{c}-0.0003^{\star *} \\
(0.0001)\end{array}$ & $\begin{array}{l}-0.0001 \\
(0.0002)\end{array}$ \\
\hline Current Account & $\begin{array}{l}-0.01 \\
(0.01)\end{array}$ & $\begin{array}{c}-0.001 \\
(0.02)\end{array}$ & $\begin{array}{l}0.01 \\
(0.01)\end{array}$ & $\begin{array}{l}0.01 \\
(0.01)\end{array}$ & $\begin{array}{c}-0.002 \\
(0.02)\end{array}$ \\
\hline Changes in net Reserves & $\begin{array}{c}-3.89^{*} \\
(2.07)\end{array}$ & $\begin{array}{l}0.19 \\
(3.17)\end{array}$ & $\begin{array}{l}-2.89 \\
(2.09)\end{array}$ & $\begin{array}{l}-2.09 \\
(2.07)\end{array}$ & $\begin{array}{l}0.05 \\
(3.22)\end{array}$ \\
\hline GDP/capita (1995 PPP) & $\begin{array}{c}-0.00003 \\
(0.00003)\end{array}$ & $\begin{array}{c}-0.001^{\star \star} \\
(0.0002)\end{array}$ & $\begin{array}{c}-0.0001^{*} \\
(0.00004)\end{array}$ & $\begin{array}{c}-0.0001^{\star *} \\
(0.00004)\end{array}$ & $\begin{array}{c}-0.001^{\star *} \\
(0.0002)\end{array}$ \\
\hline Growth & $\begin{array}{l}-0.001 \\
(0.005)\end{array}$ & $\begin{array}{c}-0.003 \\
(0.02)\end{array}$ & $\begin{array}{l}-0.003 \\
(0.004)\end{array}$ & $\begin{array}{l}-0.002 \\
(0.004)\end{array}$ & $\begin{array}{c}-0.004 \\
(0.02)\end{array}$ \\
\hline Regime & $\begin{array}{l}0.04 \\
(0.19)\end{array}$ & $\begin{array}{l}0.32 \\
(0.39)\end{array}$ & $\begin{array}{l}0.18 \\
(0.20)\end{array}$ & $\begin{array}{l}0.18 \\
(0.18)\end{array}$ & $\begin{array}{l}0.26 \\
(0.41)\end{array}$ \\
\hline log(checks) & $\begin{array}{l}0.08 \\
(0.14)\end{array}$ & $\begin{array}{l}0.13 \\
(0.25)\end{array}$ & $\begin{array}{l}0.16 \\
(0.14)\end{array}$ & $\begin{array}{l}0.07 \\
(0.10)\end{array}$ & $\begin{array}{l}0.06 \\
(0.24)\end{array}$ \\
\hline Africa & & & $\begin{array}{l}0.39 \\
(0.25)\end{array}$ & $\begin{array}{c}0.41^{\star *} \\
(0.19)\end{array}$ & \\
\hline Asia & & & $\begin{array}{l}-0.05 \\
(0.27)\end{array}$ & $\begin{array}{l}-0.06 \\
(0.23)\end{array}$ & \\
\hline \multicolumn{6}{|l|}{ MidEast/ N.Africa } \\
\hline Latin America /Caribbean & & & $\begin{array}{l}0.32 \\
(0.25)\end{array}$ & $\begin{array}{c}0.43^{\star *} \\
(0.15)\end{array}$ & \\
\hline Eastern Europe & & & $\begin{array}{c}2.48^{\star *} \\
(0.43)\end{array}$ & $\begin{array}{c}2.44^{\star \star} \\
(0.46)\end{array}$ & \\
\hline \multicolumn{6}{|l|}{ Indust. Countries } \\
\hline Non-Partic. Years & & & & & $\begin{array}{c}-0.67^{\star *} \\
(0.06)\end{array}$ \\
\hline Spline 1 & & & & & $\begin{array}{l}-0.001^{\star *} \\
(0.0002)\end{array}$ \\
\hline Spline 2 & & & & & $\begin{array}{c}-0.01^{\star \star} \\
(0.002)\end{array}$ \\
\hline Spline 3 & & & & & $\begin{array}{c}0.005^{\star \star} \\
(0.001)\end{array}$ \\
\hline Constant & $\begin{array}{l}-1.25^{\star *} \\
(0.38)\end{array}$ & & $\begin{array}{c}-1.72^{\star *} \\
(0.46)\end{array}$ & & \\
\hline $\begin{array}{c}\text { \# of obs. } \\
\text { \# of countries }\end{array}$ & $\begin{array}{c}1,210 \\
92\end{array}$ & $\begin{array}{l}996 \\
61\end{array}$ & $\begin{array}{c}1,210 \\
92\end{array}$ & $\begin{array}{c}1,210 \\
92\end{array}$ & $\begin{array}{l}996 \\
61\end{array}$ \\
\hline Log pseudolikelihood & -693.00 & -397.67 & -668.10 & -604.52 & -345.25 \\
\hline
\end{tabular}


Table 4: Tests using the "stripped specification" large sample

\begin{tabular}{|c|c|c|c|c|c|}
\hline & Pooled Logit & $\begin{array}{c}\text { Conditional Logit } \\
\text { (Country Fixed } \\
\text { Effects) }\end{array}$ & $\begin{array}{c}\text { Pooled Logit with } \\
\text { Regional Fixed } \\
\text { Effects }\end{array}$ & $\begin{array}{c}\text { Conditional Logit } \\
\text { (Year Fixed Effects) }\end{array}$ & $\begin{array}{c}\text { Conditional Logit } \\
\text { with Temporal } \\
\text { Splines }\end{array}$ \\
\hline UNSC & $\begin{array}{l}\mathbf{0 . 3 1} 1^{* *} \\
(0.14)\end{array}$ & $\begin{array}{l}\mathbf{0 . 3 7} 7^{\star *} \\
(0.13)\end{array}$ & $\begin{array}{l}\mathbf{0 . 3 3}^{\text {** }} \\
(0.14)\end{array}$ & $\begin{array}{l}\mathbf{0 . 3 6} 6^{\star *} \\
(0.14)\end{array}$ & $\begin{array}{l}\mathbf{0 . 2 8 ^ { * }} \\
(0.15)\end{array}$ \\
\hline Past Participation & $\begin{array}{l}3.15^{\star \star} \\
(0.10)\end{array}$ & $\begin{array}{l}3.34^{\star \star} \\
(0.16)\end{array}$ & $\begin{array}{l}3.17^{\star *} \\
(0.11)\end{array}$ & $\begin{array}{l}3.16^{\star \star} \\
(0.13)\end{array}$ & $\begin{array}{l}2.21^{\star *} \\
(0.18)\end{array}$ \\
\hline GDP/capita (1995 PPP) & $\begin{array}{l}-0.0002^{\star *} \\
(0.00001)\end{array}$ & $\begin{array}{l}-0.0004^{\star *} \\
(0.00006)\end{array}$ & $\begin{array}{l}-0.0002^{\star *} \\
(0.00002)\end{array}$ & $\begin{array}{l}-0.0002^{\star \star} \\
(0.00002)\end{array}$ & $\begin{array}{l}-0.0003^{\star *} \\
(0.00004)\end{array}$ \\
\hline Regime & $\begin{array}{c}-0.24^{\star *} \\
(0.08)\end{array}$ & $\begin{array}{l}-0.22 \\
(0.17)\end{array}$ & $\begin{array}{l}-0.17^{*} \\
(0.09)\end{array}$ & $\begin{array}{l}-0.05 \\
(0.09)\end{array}$ & $\begin{array}{c}-0.29 * \star \\
(0.14)\end{array}$ \\
\hline Africa & & & $\begin{array}{l}0.64^{\star \star} \\
(0.14)\end{array}$ & $\begin{array}{l}0.65^{\star \star} \\
(0.12)\end{array}$ & \\
\hline Asia & & & $\begin{array}{c}0.26 \\
(0.16)\end{array}$ & $\begin{array}{l}0.31^{*} \\
(0.16)\end{array}$ & \\
\hline MidEast/ N.Africa & & & $\begin{array}{l}0.81^{\star *} \\
(0.14)\end{array}$ & $\begin{array}{l}0.86^{\star *} \\
(0.12)\end{array}$ & \\
\hline \multicolumn{6}{|l|}{ Latin America /Caribbean } \\
\hline Eastern Europe & & & $\begin{array}{l}2.03^{\star *} \\
(0.19)\end{array}$ & $\begin{array}{l}2.02^{\star \star} \\
(0.20)\end{array}$ & \\
\hline Indust. Countries & & & $\begin{array}{l}-0.06 \\
(0.25)\end{array}$ & $\begin{array}{l}-0.07 \\
(0.19)\end{array}$ & \\
\hline Non-Partic. Years & & & & & $\begin{array}{c}-0.69 * * \\
(0.03)\end{array}$ \\
\hline Spline 1 & & & & & $\begin{array}{l}-0.001^{\star *} \\
(0.0001)\end{array}$ \\
\hline Spline 2 & & & & & $\begin{array}{l}-0.01^{\star *} \\
(0.001)\end{array}$ \\
\hline Spline 3 & & & & & $\begin{array}{c}0.005^{\star *} \\
(0.0005)\end{array}$ \\
\hline Constant & $\begin{array}{c}-1.98^{\star \star} \\
(0.13)\end{array}$ & & $\begin{array}{c}-2.68^{\star \star} \\
(0.20)\end{array}$ & & \\
\hline \# of obs. & 5,625 & 4,448 & 5,625 & 5,575 & 4,448 \\
\hline \# of countries & 176 & 127 & 176 & 168 & 127 \\
\hline Log pseudolikelihood & -2341.76 & -1749.17 & -2255.14 & -2096.38 & -1498.32 \\
\hline
\end{tabular}

\section{Results}

Table 1 presents the results of the bivariate analysis under various statistical models. The effect of UN Security Council membership on IMF participation is positive, highly significant, and substantial. In the most basic pooled logit model, and in line with Figure 1, the estimated probability of IMF participation increases by over 25 percent for countries entering the Security Council. 
The statistically significant relationship between UN Security Council membership and IMF participation holds when we introduce country fixed effects, employing Chamberlain's (1980) conditional logit. Note that the number of observations drops from 7,606 to 5,694 because countries where there is no variation in the dependent variable have no impact on the likelihood function.

Next we introduce fixed effects for the following regions or groups: Africa, Asia, Middle East/North Africa, Latin America/Caribbean, Eastern Europe, Industrialized Countries. As with any complete set of dummy variables, one must be left out of the analysis. In table 1, we omit Eastern Europe. So the significantly positive coefficients for Africa and Latin America/Caribbean indicate that these regions are more likely to participate in IMF programs than Eastern Europe; the significantly negative coefficients for Asia, Middle East/North Africa, and Industrialized Countries indicate that these regions are less likely to participate in IMF programs than Eastern Europe. The main point of this model, however, is that the significantly positive relationship between UN Security Council membership and IMF participation persists.

The final model in table 1 introduces Beck, Katz, and Tucker's (1998) correction for duration dependence in the data. Duration dependence is significant, with countries significantly more likely to participate again if they have participated in the recent past. Even accounting for this time trend in the data, the positive effect of UN Security Council membership is significant.

In table 2, we introduce a "robust variable" specification into the various statistical models. The robust predictors - foreign reserves, debt service, investment, past participation, and lagged election - are suggested by the Extreme Bounds Analysis of Sturm, Berger and de Haan (2005).

Foreign Reserves, measured as average annual reserves in terms of monthly imports, come from World Development Indicators (2004). The variable has the expected negative effect - stronger reserves lead to less need for IMF loans - however, the effect is not statistically significant in the two models where we include country fixed effects. We suspect that the country effects may be picking up the effects of exchange rate regime, following Trudel (2005). Note that countries with a floating exchange rate do not require IMF loans to shore up their currency. 
Debt service, measured as public and publicly guaranteed debt service as a percentage of gross national income, comes from World Development Indicators (2004). The variable has a strongly positive significant effect in all of our models. More debt leads to more need for the IMF. The effect is not surprising. Many creditors, such as the Paris Club, for example, require an IMF arrangement to be in good standing for debt negotiations to take place. ${ }^{29}$

Investment, measured as private and public gross national investment as a share of gross domestic product (GDP), comes from Penn World Tables 6.1. ${ }^{30}$ This variable also has a remarkably robust negative significant effect on IMF participation. Lower investment leads to IMF participation.

Past participation, measured as a dummy variable coded 1 for countries that have previously participated in IMF programs and 0 otherwise, has a positive significant effect in most models. Note that the effect goes away in the more sophisticated model capturing duration dependence. ${ }^{31}$

Finally, we include lagged elections, which is a dummy variable coded 1 if elections were held the previous year and 0 otherwise. ${ }^{32}$ It has been argued that IMF involvement is more likely after national elections, as new governments can blame their predecessor for the economic crisis (Przeworski and Vreeland 2000, also see Smith and Vreeland 2006) or Fund conditionality is used to fight the effects of expansionary policies in the run up to the election (Dreher and Vaubel 2004a). The election dummy has the expected positive effect - however, it is not significant at conventional levels of significance.

Turning to our principal independent variable of interest, UNSC membership has a positive effect on IMF participation in all of our models. The finding is significant at

\footnotetext{
${ }^{29}$ Marchesi (2003) tests whether countries having arrangements with the IMF are more likely to obtain a rescheduling of their external debt than others. She concludes that the adoption of an IMF program works as signal of a country's "good intent" which is rewarded with debt relief. Her results confirm the existence of a significant effect of the adoption of an IMF program on the subsequent concession of a debt rescheduling by private creditors.

${ }^{30}$ These data come from Przeworski et al. (2000), extended by Jose Antonio Cheibub, Jennifer Gandhi, Adam Przeworski, and Sebastian Saiegh.

${ }^{31}$ This is not simply due to multicolinearity. The correlation of Past Participation and Non-Participation Years is -0.44 , and the correlations of Past Participation and the three Splines are 0.27, 0.33, and 0.30, respectively.

32 The data is derived from the Database of Political Institutions (Beck et al. 1999).
} 
the 5 percent level in all models except the one including regional fixed effects. Even here, the effect is significant at the 10 percent level. Note that with the loss of observations due to missing data in our control variables, the sample size is reduced to just 1,839 observations. Both the dummy variables for Eastern Europe and Industrialized Countries are dropped because of insufficient IMF participation in these regions. After we account for their economic problems (by controlling for Foreign Reserves, Debt Service, and Investment), Africa, Asia, Middle East/North Africa, and Latin America/Caribbean are all less likely to participate in IMF programs than Eastern Europe. When we introduce fixed effects for years, the results persist. However, in this model, the significance of the positive effect of UNSC membership increases to the 5 percent level.

Even after introducing control variables, the impact of UNSC membership remains substantial. In the pooled logit, for example, the baseline probability of IMF participation holding all variables to their mean is 0.47 if a country does not serve on the UNSC. For temporary members of the UNSC, however, the probability of IMF participation is 0.58 - an increase of more than 20 percent over the baseline probability. ${ }^{33}$

In table 3, we introduce several additional control variables, which have been cited in the literature as being important for participation in IMF programs: Budget Surplus, Inflation, Current Account Balance, Change in Reserves, GDP per capita (1995 PPP), Dictatorial Regime, and the number of veto players in the political system, measured as the natural logarithm of the sum of the chief executive, each house of the legislature, and the coalition parties forming the government $(\log ($ checks $)) .{ }^{34}$ Consistent with Sturm, Berger and de Haan (2005), these variables do not have robust effects across our various statistical models.

For example, Budget Surplus, measured as the overall budget balance as a percentage of GDP, changes signs and significance. ${ }^{35}$ Inflation, from World Development

\footnotetext{
${ }^{33}$ We also tested whether the relationship between UNSC membership and IMF programs displays a structural break with the end of the Cold War. We do not find evidence in favor of this hypothesis.

34 The "checks" variable comes from the Database of Political Institutions (Beck et al. 1999). For more on the definition and on the relationship to IMF participation, see Vreeland $(2003,2005)$.

${ }^{35}$ Data come from World Development Indicators 2004. Przeworski and Vreeland (2002) also find that Budget Surplus is not significant in a univariate probit model, but in a bivariate probit model, where supply and demand of IMF programs are modeled as separate functions, Budget Surplus has a negative significant effect.
} 
Indicators 2004 where it is defined as the percentage change in consumer prices, has the expected negative effect throughout, but is not always significant. Current Account Balance (World Development Indicators 2004), measured as a percentage of GDP, is never significant at conventional levels, despite the fact that this should predict IMF participation, at least according to the IMF Articles of Agreement. The Change in net Reserves as a proportion of GDP (World Development Indicators 2004) also changes signs and significance depending on the model. GDP per capita, measured in 1995 PPP dollars, has a fairly robust negative effect - poorer countries are more likely to turn to the IMF. $^{36}$ Dictatorial Regime, a dummy variable coded 1 for dictatorships and 0 for democracy (from Przeworski et al. 2000, updated by Cheibub and Gandhi 2004), has a positive but insignificant effect. The number of veto players in the political system $(\log ($ checks $))$ has the expected positive effect, though it is not significant.

What is remarkable for the purposes of this study is that UNSC membership has a strong positive significant impact on IMF participation, regardless of the covariates and statistical model employed. With pooled logit, for example, holding all variables to their means, the estimated probability of IMF participation increases from 0.50 to 0.64 when a country serves as a temporary member of the UNSC.

Note that the baseline estimated probabilities in tables 2 and 3 are almost double the estimated baseline probability from table 1 ( 0.47 and 0.50 versus 0.26$)$. This is because governments participate at much higher rates in the smaller samples considered in tables 2 and 3 than in the full sample of observations. One reason for this is that data are more likely to be reported by countries participating in IMF programs than countries that are not under surveillance (Rosendorff and Vreeland 2006).

Indeed, some model specifications of table 3 analyze less than 1,000 observations, down from the original 7,606. This is a potential problem that we address in table 4, where we introduce the "stripped specification" large sample. The largest sample, presented in table 1, shows that the bivariate correlation between UNSC membership and IMF participation holds for the entire set of data. Tables 2 and 3 show that the correlation holds when control variables are introduced, even though the sample size is dramatically

\footnotetext{
${ }^{36}$ The data come from Penn World Tables 6.1. Our version comes from Przeworski et al. (2000), extended by Jose Antonio Cheibub, Jennifer Gandhi, Adam Przeworski, and Sebastian Saiegh.
} 
reduced. In table 4, we present a specification that is in between: we introduce some control variables, but only those for which there are ample data. We therefore exclude all control variables that, if included, would reduce the number of observations below 4,000 . This allows us to test the generality of our finding while still controlling for some variables that may affect IMF participation. The number of observations we analyze with this stripped specification ranges from 4,448 to 5,625 .

We include Past Participation, GDP per capita, and Regime. Interestingly, GDP per capita and Past Participation affect IMF program participation in all specifications, with coefficients being significant at the five percent level. Countries with past participation are more likely to return to the IMF, even controlling for duration dependence with temporal splines; poor countries are more likely to turn to the IMF. In some specifications we also find that democracies are more likely to participate in IMF programs.

Regardless, and most important for our analysis, we find that the positive significant effect of UNSC membership persists. Only in the large sample with temporal splines does the significance of UNSC membership drop just below the 5 percent level of significance, although the impact is significant at the 10 percent level. Given our strongly significant results with this duration dependence model from table 1 - with the largest sample and no controls - and table 3 - with the smallest sample and a full set of control variables - we suspect that the drop in significance here has more to do with this specific sample than with omitted variable bias. Overall, the impact of UNSC membership remains substantial with the "stripped specification" models. The predicted baseline probability in the pooled logit model is 0.17 for non-UNSC members, and 0.22 for UNSC members - an increase of over 25 percent.

To summarize this section, using a battery of different statistical models, different control variables, and different samples, we find a robust impact of UNSC membership increasing the likelihood of participation in IMF programs. We take this as evidence of our argument that the G7 use the IMF to pursue international political goals. 


\section{Extensions and tests for robustness}

In this section, we present several extensions to our basic analysis. First, we investigate the timing of UNSC membership influence on IMF programs in greater detail. Recall Figure 2, where we display rates of participation in IMF programs before, during and after membership. IMF participation appears to increase with the onset of UNSC membership and decrease afterwards. Does this trend hold up to more rigorous tests? Following Kuziemko and Werker (2005), we employ a series of dummy variables to examine this trend over time. ${ }^{37}$

As our second extension, we investigate whether the increased participation in IMF programs while on the UN Security Council can be attributed to the increased attention a country might receive at the world political stage while on the UNSC. We therefore replicate the analysis distinguishing between countries either belonging to the Eastern or Western block or, alternatively, have been un-aligned during the Cold War. If the impact of being on the Security Council on IMF programs is driven by countries exerting their influence in a way correlated with both gaining a UNSC seat and getting approval by the IMF, we would expect to observe the same impact of membership on IMF program participation among both groups. If, to the contrary, vote buying with IMF programs drives the result, we would expect to find the impact in the sample of nonaligned countries only, as countries of the Eastern or Western block are unlikely to ask for or accept bribes for voting against "their" block. ${ }^{38}$

As our third extension, we examine the robustness of the relationship between UNSC membership and IMF program participation with Extreme Bounds Analysis. Hundreds of specifications with different combinations of control variables are analyzed. The EBA approach is described in detail in Appendix A. Following Sala-i-Martin (1997),

\footnotetext{
${ }^{37} \mathrm{We}$ also tested whether there is an interaction between our democratic regime variable and UNSC membership. As has been argued by Kuziemko and Werker (2005), dictatorships might be easier and more likely to be bribed. The same might hold for closer allies of the US (Kuziemko and Werker 2005). We follow the previous literature and measure political proximity to the US by a country's voting pattern in the UN General Assembly. However, we do not find any significant impact.

${ }^{38}$ Following Kuziemko and Werker (2005) we also tested whether the effect of UNSC membership on IMF programs increases during years in which key diplomatic events take place. Arguably, when members' votes are especially valuable, the price should increase. We employ Kuziemko and Werker's operationalization of "importance." They considered how much press the deliberations of the UNSC received in a year. Contrary to Kuziemko and Werker, however, we do not find a significant difference between "important" and "less important" years.
} 
we consider the impact of UNSC membership on IMF programs to be robust if the fraction of the cumulative distribution function lying on one side of zero exceeds 0.90 . The variables our EBA includes in all specifications are: Past Participation, GDP/capita (1995 PPP) and Regime. Each regression also includes up to three combinations of: Foreign Reserves, Debt Service, Investment, Lagged Election, Budget Surplus, Inflation, Current Account, Changes in net Reserves, Growth, and log(checks).

Fourth, we analyze the effect of UNSC membership on the number of conditions attached to IMF programs. The number of conditions has been the focus of heated debate. As one example, in 1999 United States Congress threatened to refuse ratification of the quota increase if the Fund did not reduce the stringency and number of its policy conditions (Dreher and Vaubel 2004b). The number of conditions has been used as a proxy for the stringency of conditionality in previous studies. ${ }^{39}$ According to the results of Dreher and Jensen (2007), for example, countries voting in line with the US in the UN General Assembly receive IMF programs with fewer conditions. Analogously, we expect that temporary members of the Security Council also receive programs with fewer conditions.

Our data on the number of IMF conditions are from Dreher (2004), extended in Dreher and Jensen (2007). They refer to 206 IMF letters of intent with 38 countries between 1997 and $2003 .{ }^{40}$ Note that we have far fewer observations of the number of conditions than we do of IMF participation. This is because for most of its history, the IMF has been a highly secretive, non-transparent institution. In the past, the details of IMF arrangements were not released to the public for years, and even when released they were kept at the IMF archives, not easily available to the public. Since the late 1990s, the institution has opened up and recent IMF arrangements are posted on the Fund web page (www.imf.org). With so few observations, analysis is tentative. Nevertheless, we put the

\footnotetext{
${ }^{39}$ See IMF (2001), Gould (2003), Dreher (2004), Bulír and Moon (2004), Dreher and Vaubel (2004b), Ivanova, Mayer, and Mourmouras (2005), and Dreher and Jensen (2007).

${ }^{40}$ The following countries and number of letters are included in the sample: Albania (5 letters of intent), Argentina (3), Armenia (5), Azerbaijan (3), Belarus (1), Benin (5), Bolivia (4), Brazil (6), Bulgaria (3), Burkina Faso (8), Cambodia (3), Cameroon (3), Cape Verde (2), Central African Republic (3), Colombia (5), Croatia (5), Estonia (3), Georgia (3), Ghana (4), Guinea (5), Indonesia (11), Jordan (4), Kazakhstan (1), Korea (7), Latvia (4), Mali (5), Moldova (2), Nicaragua (5), Pakistan (1), Panama (8), Peru (6), Russia (2), Rwanda (6), Sao Tome and Principe (5), Uganda (5), Uruguay (6), and Zimbabwe (1). We tried replicating the analysis using the IMF's Monitoring Fund Arrangements (MONA) database. However, only two of the program countries with data available served on the UNSC while being under a program.
} 
data to rigorous testing. Since the data on conditions are strongly skewed to the right, estimation with Poisson regressions might be appropriate. However, the data display significant over-dispersion, so we estimate Negative Binomial Regressions instead.

Finally, as a fifth extension, we investigate whether UNSC membership also influences the size of IMF loans. It has been shown that countries voting with the US in the UN General Assembly receive larger IMF loans (Oatley and Yackee 2004). When the IMF's major shareholders use the Fund to bribe or reward temporary UNSC members, we expect them to receive larger loans, all else equal.

Table 5 presents results regarding the timing of UNSC membership influence on IMF programs. We include a series of dummy variables for the year before UNSC membership, the first year of membership, the second, and the year after membership ends. The statistical model we employ throughout the table is the one we consider to be the most rigorous and most appropriate - conditional logit with temporal splines. We employ the same sets of control variables used in tables 2 through 4 above. As indicated by the statistically significant coefficients for the UNSC Year 1 dummy variable, the impact of UNSC membership is strongest during the first year of the two-year term. We employ the UNSC Year 1 dummy variable in tandem with the other year dummies (following Figure 2 above), and we also find the result holds when we test the UNSC Year 1 dummy by itself. The results make sense when IMF programs are employed to bribe temporary Security Council members. Almost all IMF arrangements last a minimum of 18 months, so participation should be strongest during the first year. 
Table 5: Trends over time

\begin{tabular}{|c|c|c|c|c|c|c|c|c|}
\hline \multirow[b]{3}{*}{ UNSC 1 year before } & \multicolumn{8}{|c|}{ Conditional Logit (Country Fixed Effects) } \\
\hline & \multicolumn{2}{|c|}{ Barebones } & \multicolumn{2}{|c|}{ Robust variables } & \multicolumn{2}{|c|}{ Other controls } & \multicolumn{2}{|c|}{ Large sample } \\
\hline & $\begin{array}{l}0.20 \\
(0.18)\end{array}$ & & $\begin{array}{c}0.07^{\star *} \\
(0.30)\end{array}$ & & $\begin{array}{l}0.09 \\
(0.33)\end{array}$ & & $\begin{array}{l}0.26 \\
(0.21)\end{array}$ & \\
\hline UNSC year 1 & $\begin{array}{c}0.39 * * \\
(0.17)\end{array}$ & $\begin{array}{l}0.37^{\star *} \\
(0.16)\end{array}$ & $\begin{array}{l}0.65^{\star} \\
(0.32)\end{array}$ & $\begin{array}{l}0.67^{\star *} \\
(0.30)\end{array}$ & $\begin{array}{c}1.23^{* *} \\
(0.42)\end{array}$ & $\begin{array}{c}1.28^{\star *} \\
(0.38)\end{array}$ & $\begin{array}{l}0.38^{\star *} \\
(0.17)\end{array}$ & $\begin{array}{l}0.35^{\star \star} \\
(0.17)\end{array}$ \\
\hline UNSC year 2 & $\begin{array}{l}0.22 \\
(0.21)\end{array}$ & & $\begin{array}{l}0.23 \\
(0.34)\end{array}$ & & $\begin{array}{l}0.00 \\
(0.36)\end{array}$ & & $\begin{array}{l}0.20 \\
(0.23)\end{array}$ & \\
\hline UNSC 1 year after & $\begin{array}{l}-0.11 \\
(0.17)\end{array}$ & & $\begin{array}{l}-0.52^{*} \\
(0.34)\end{array}$ & & $\begin{array}{l}-0.64^{*} \\
(0.44)\end{array}$ & & $\begin{array}{l}-0.18 \\
(0.20)\end{array}$ & \\
\hline Foreign Reserves & & & $\begin{array}{l}-0.03 \\
(0.06)\end{array}$ & $\begin{array}{l}-0.03 \\
(0.06)\end{array}$ & $\begin{array}{l}-0.04 \\
(0.08)\end{array}$ & $\begin{array}{l}-0.04 \\
(0.08)\end{array}$ & & \\
\hline Debt Service & & & $\begin{array}{l}0.02^{\star *} \\
(0.01)\end{array}$ & $\begin{array}{l}0.02^{\star *} \\
(0.01)\end{array}$ & $\begin{array}{l}0.02^{\star *} \\
(0.01)\end{array}$ & $\begin{array}{l}0.02^{\star *} \\
(0.01)\end{array}$ & & \\
\hline Investment & & & $\begin{array}{c}-0.04^{\star *} \\
(0.02)\end{array}$ & $\begin{array}{c}-0.04^{\star *} \\
(0.02)\end{array}$ & $\begin{array}{l}-0.05 \\
(0.04)\end{array}$ & $\begin{array}{l}-0.05 \\
(0.04)\end{array}$ & & \\
\hline Past Participation & & & $\begin{array}{l}0.99 \\
(0.72)\end{array}$ & $\begin{array}{l}1.01 \\
(0.72)\end{array}$ & $\begin{array}{l}2.00^{*} \\
(1.19)\end{array}$ & $\begin{array}{l}2.02^{*} \\
(1.16)\end{array}$ & $\begin{array}{l}2.21^{\star *} \\
(0.18)\end{array}$ & $\begin{array}{l}2.21^{\star \star} \\
(0.18)\end{array}$ \\
\hline Lagged Election & & & $\begin{array}{l}0.22 \\
(0.18)\end{array}$ & $\begin{array}{l}0.20 \\
(0.19)\end{array}$ & $\begin{array}{l}-0.07 \\
(0.22)\end{array}$ & $\begin{array}{l}-0.09 \\
(0.22)\end{array}$ & & \\
\hline Budget Surplus & & & & & $\begin{array}{c}0.06^{* *} \\
(0.03)\end{array}$ & $\begin{array}{c}0.06^{\star *} \\
(0.03)\end{array}$ & & \\
\hline Inflation & & & & & $\begin{array}{c}-0.0001 \\
(0.0002)\end{array}$ & $\begin{array}{c}-0.0001 \\
(0.0002)\end{array}$ & & \\
\hline Current Account & & & & & $\begin{array}{l}-0.002 \\
(0.019)\end{array}$ & $\begin{array}{l}-0.002 \\
(0.019)\end{array}$ & & \\
\hline BOP & & & & & $\begin{array}{l}0.10 \\
(3.26)\end{array}$ & $\begin{array}{l}-0.20 \\
(3.34)\end{array}$ & & \\
\hline GDP/capita (1995 PPP) & & & & & $\begin{array}{c}-0.0006^{\star *} \\
(0.0002)\end{array}$ & $\begin{array}{c}-0.0006^{\star *} \\
(0.0002)\end{array}$ & $\begin{array}{c}-0.0003^{* *} \\
(0.0000)\end{array}$ & $\begin{array}{c}-0.0003^{* *} \\
(0.0000)\end{array}$ \\
\hline Growth & & & & & $\begin{array}{l}-0.01 \\
(0.02)\end{array}$ & $\begin{array}{l}-0.01 \\
(0.02)\end{array}$ & & \\
\hline Regime & & & & & $\begin{array}{l}0.25 \\
(0.41)\end{array}$ & $\begin{array}{l}0.26 \\
(0.41)\end{array}$ & $\begin{array}{c}-0.29^{\star *} \\
(0.14)\end{array}$ & $\begin{array}{c}-0.29 * \star \\
(0.14)\end{array}$ \\
\hline $\log ($ checks) & & & & & $\begin{array}{l}0.05 \\
(0.24)\end{array}$ & $\begin{array}{l}0.06 \\
(0.24)\end{array}$ & & \\
\hline Non-Partic. Years & $\begin{array}{c}-0.84^{\star *} \\
(0.03)\end{array}$ & $\begin{array}{c}-0.84^{\star *} \\
(0.03)\end{array}$ & $\begin{array}{c}-0.70^{\star *} \\
(0.05)\end{array}$ & $\begin{array}{c}-0.70 \text { ** } \\
(0.05)\end{array}$ & $\begin{array}{c}-0.69 * * \\
(0.06)\end{array}$ & $\begin{array}{c}-0.68^{\star *} \\
(0.06)\end{array}$ & $\begin{array}{c}-0.69 * * \\
(0.03)\end{array}$ & $\begin{array}{c}-0.69 * * \\
(0.03)\end{array}$ \\
\hline Spline 1 & $\begin{array}{c}-0.0004^{* *} \\
(0.0001)\end{array}$ & $\begin{array}{c}-0.0004^{* *} \\
(0.0001)\end{array}$ & $\begin{array}{c}-0.0003^{\star *} \\
(0.0002)\end{array}$ & $\begin{array}{c}-0.0003^{\star \star} \\
(0.0002)\end{array}$ & $\begin{array}{c}-0.0006^{\star \star} \\
(0.0002)\end{array}$ & $\begin{array}{c}-0.0006^{\star \star} \\
(0.0002)\end{array}$ & $\begin{array}{c}-0.0006 * * \\
(0.0001)\end{array}$ & $\begin{array}{c}-0.0006 * \star \\
(0.0001)\end{array}$ \\
\hline Spline 2 & $\begin{array}{c}-0.0092^{\star *} \\
(0.0005)\end{array}$ & $\begin{array}{c}-0.0092^{\star *} \\
(0.0005)\end{array}$ & $\begin{array}{c}-0.0079^{\star *} \\
(0.0013)\end{array}$ & $\begin{array}{c}-0.0078^{\star *} \\
(0.0013)\end{array}$ & $\begin{array}{c}-0.0093^{\star \star} \\
(0.0019)\end{array}$ & $\begin{array}{c}-0.0093^{* *} \\
(0.0019)\end{array}$ & $\begin{array}{c}-0.0093^{\star *} \\
(0.0007)\end{array}$ & $\begin{array}{c}-0.0093^{* \star} \\
(0.0007)\end{array}$ \\
\hline Spline 3 & $\begin{array}{c}0.0043^{* *} \\
(0.0003)\end{array}$ & $\begin{array}{c}0.0043^{* *} \\
(0.0003)\end{array}$ & $\begin{array}{c}0.0037^{\star \star} \\
(0.0010)\end{array}$ & $\begin{array}{c}0.0037^{\star *} \\
(0.0010)\end{array}$ & $\begin{array}{c}0.0049 * * \\
(0.0012)\end{array}$ & $\begin{array}{c}0.0049 * * \\
(0.0012)\end{array}$ & $\begin{array}{c}0.0050^{\star *} \\
(0.0005)\end{array}$ & $\begin{array}{c}0.0050^{\star *} \\
(0.0005)\end{array}$ \\
\hline \# of obs. & 5,694 & 5,694 & 1,570 & 1,570 & 996 & 996 & 4,448 & 4,448 \\
\hline \# of countries & 137 & 137 & 82 & 82 & 61 & 61 & 125 & 125 \\
\hline Log pseudolikelihood & -2039.27 & -2040.40 & -562.51 & -564.14 & -341.97 & -343.16 & -1497.07 & -1498.54 \\
\hline
\end{tabular}

Robust standard errors are in parentheses; ** indicates significance at the $5 \%$ level; and * indicates significance at the $10 \%$ level. 
Table 6: Differences across non-aligned and aligned countries during the Cold War

\begin{tabular}{|c|c|c|c|}
\hline & $\begin{array}{c}\text { Stripped specification or large } \\
\text { sample from table } 4\end{array}$ & $\begin{array}{c}\text { Not aligned countries during } \\
\text { the Cold War }\end{array}$ & $\begin{array}{c}\text { Aligned countries during the } \\
\text { Cold War }\end{array}$ \\
\hline UNSC & $\begin{array}{l}\mathbf{0 . 2 8 *} \\
(0.15)\end{array}$ & $\begin{array}{l}\mathbf{0 . 5 3 * *} \\
(0.27)\end{array}$ & $\begin{array}{l}-0.22 \\
(0.30)\end{array}$ \\
\hline Past Participation & $\begin{array}{l}2.21^{\star \star} \\
(0.18)\end{array}$ & $\begin{array}{l}2.64^{\star *} \\
(0.26)\end{array}$ & $\begin{array}{l}1.41^{\star \star} \\
(0.40)\end{array}$ \\
\hline GDP/capita (1995 PPP) & $\begin{array}{l}-0.0003^{\star *} \\
(0.00004)\end{array}$ & $\begin{array}{l}-0.0005^{\star *} \\
(0.00012)\end{array}$ & $\begin{array}{l}-0.0001 \\
(0.00007)\end{array}$ \\
\hline Regime & $\begin{array}{l}-0.29 \star \star \\
(0.14)\end{array}$ & $\begin{array}{l}0.13 \\
(0.26)\end{array}$ & $\begin{array}{l}-0.09 \\
(0.44)\end{array}$ \\
\hline Non-Partic. Years & $\begin{array}{l}-0.69 * \star \\
(0.03)\end{array}$ & $\begin{array}{l}-0.68^{\star *} \\
(0.04)\end{array}$ & $\begin{array}{l}-0.68^{\star \star} \\
(0.05)\end{array}$ \\
\hline Spline 1 & $\begin{array}{l}-0.001^{\star \star} \\
(0.0001)\end{array}$ & $\begin{array}{l}-0.003^{\star \star} \\
(0.0009)\end{array}$ & $\begin{array}{l}-0.003^{\star \star} \\
(0.0011)\end{array}$ \\
\hline Spline 2 & $\begin{array}{l}-0.01^{\star *} \\
(0.001)\end{array}$ & $\begin{array}{l}-0.01^{\star *} \\
(0.001)\end{array}$ & $\begin{array}{l}-0.01 * \star \\
(0.002)\end{array}$ \\
\hline Spline 3 & $\begin{array}{l}0.005^{\star *} \\
(0.0005)\end{array}$ & $\begin{array}{l}0.010^{* *} \\
(0.0018)\end{array}$ & $\begin{array}{l}-0.011^{\star *} \\
(0.0019)\end{array}$ \\
\hline \# of obs. & 4,448 & 2,198 & 925 \\
\hline \# of countries & 125 & 73 & 26 \\
\hline Log pseudolikelihood & -1498.32 & -708.25 & -294.32 \\
\hline
\end{tabular}

All regressions in this table use conditional logit with country fixed effects and temporal splines.

Robust standard errors are in parentheses; ** indicates significance at the $5 \%$ level; and * indicates significance at the $10 \%$ level.

Table 6 contains the results separated along the aligned/non-aligned dimension. The first column of table 6 replicates column 5 of table 4 for comparison. As can be seen, and in line with our hypothesis, UNSC membership significantly increases the number of IMF programs for non-aligned countries only. We interpret this as clear evidence that votebuying behavior in the Security Council does indeed exist. When evaluating the quantitative impact of UNSC membership on IMF programs, the result shows that the baseline probability of 0.39 of being under an IMF program increases by more than 13 percentage points (holding the fixed effects to zero and all other variables to their means).

The result also shows that the coefficient for non-aligned countries is almost twice as high as compared to the full sample. According to the estimate of column 2, Security Council membership increases the probability of being under an IMF program by more than 50 percent. 
Results of the Extreme Bounds Analysis are summarized in table 7. We present two models: Conditional logit with fixed country effects and conditional logit with regional and year fixed effects. As can be seen, the $\mathrm{CDF}(0)$ exceeds 0.9 according to both specifications based on 175 regressions each. We conclude that the relationship between UNSC membership and IMF programs is indeed robust to the inclusion of additional variables.

Table 7: Extreme bounds analysis

\begin{tabular}{ccc} 
& $\begin{array}{c}\text { Conditional Logit } \\
\text { (Country Fixed Effects) }\end{array}$ & $\begin{array}{c}\text { Conditional Logit } \\
\text { (Regional and Year } \\
\text { Fixed Effects) }\end{array}$ \\
\cline { 2 - 3 } Average Beta Coefficient & 0.51 & 0.46 \\
Average robust std. error & 0.23 & 0.19 \\
\% Sign. at 10\% level & $100.0 \%$ & $93.7 \%$ \\
CDF(0) & $98.4 \%$ & $98.8 \%$ \\
lower bound & & \\
upper bound & -0.07 & -0.13 \\
\# of combinations & 1.26 & 1.00 \\
Average \# of observations & 175 & 175 \\
\end{tabular}




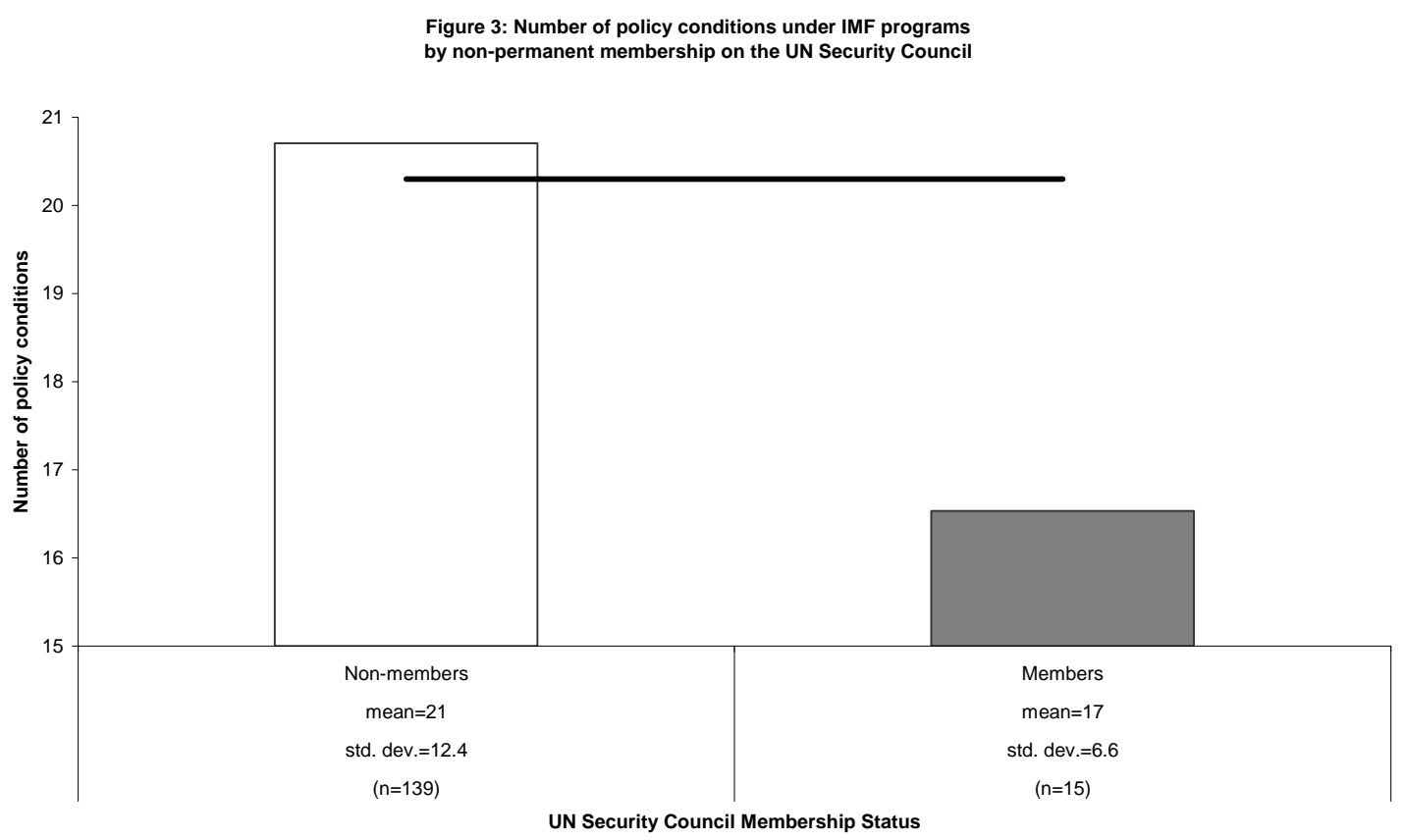

Figure 3 presents descriptive evidence of the correlation between UNSC membership and the number of conditions. Countries signing IMF arrangements during their UNSC tenure receive nearly 20 percent fewer conditions. While non-members have to accept 21 conditions on average, temporary UNSC members receive IMF programs with an average of 17 conditions. This difference is statistically significant at the 5 percent level. 
Table 8: Number of Conditions and Size of Loans

\begin{tabular}{|c|c|c|c|c|}
\hline & \multicolumn{2}{|c|}{$\begin{array}{l}\text { Number of } \\
\text { Conditions }\end{array}$} & \multirow{2}{*}{$\begin{array}{c}\text { Net } \\
\text { Loans } \\
(3) \\
\end{array}$} & \multirow{2}{*}{$\begin{array}{c}\text { Loans } \\
\text { Agreed } \\
(4) \\
\end{array}$} \\
\hline & $(1)$ & (2) & & \\
\hline UNSC & $\begin{array}{l}-0.54 * * \\
(0.26)\end{array}$ & $\begin{array}{l}-0.48^{*} \\
(0.28)\end{array}$ & $\begin{array}{l}0.008 \\
(0.05)\end{array}$ & $\begin{array}{c}\mathbf{0 . 1 4} \\
(0.32)\end{array}$ \\
\hline Foreign Reserves & $\begin{array}{l}-0.01 \\
(0.04)\end{array}$ & $\begin{array}{c}0.08 \\
(0.08)\end{array}$ & $\begin{array}{l}0.02^{\star *} \\
(0.01)\end{array}$ & $\begin{array}{l}-0.11^{*} \\
(0.06)\end{array}$ \\
\hline Debt Service & $\begin{array}{c}0.003 \\
(0.005)\end{array}$ & $\begin{array}{c}0.01 \\
(0.01)\end{array}$ & $\begin{array}{c}0.004 \\
(0.001)\end{array}$ & $\begin{array}{l}0.02 * \star \\
(0.01)\end{array}$ \\
\hline Investment & $\begin{array}{l}-0.03^{\star *} \\
(0.01)\end{array}$ & $\begin{array}{l}-0.05^{\star} \\
(0.03)\end{array}$ & $\begin{array}{l}-0.002 \\
(0.003)\end{array}$ & $\begin{array}{c}0.01 \\
(0.03)\end{array}$ \\
\hline Past Participation & & & $\begin{array}{c}0.06 \\
(0.05)\end{array}$ & $\begin{array}{c}0.21 \\
(0.31)\end{array}$ \\
\hline Lagged Election & & & $\begin{array}{c}0.02 \\
(0.03)\end{array}$ & $\begin{array}{c}0.20 \\
(0.20)\end{array}$ \\
\hline \multirow[t]{2}{*}{ Constant } & $\begin{array}{l}2.78^{* *} \\
(0.41)\end{array}$ & $\begin{array}{l}2.56^{\star \star} \\
(0.65) \\
\end{array}$ & $\begin{array}{l}-0.10 \\
(0.07) \\
\end{array}$ & $\begin{array}{l}1.26 * \star \\
(0.49)\end{array}$ \\
\hline & $\begin{array}{l}\text { Negative } \\
\text { Binomial }\end{array}$ & $\begin{array}{l}\text { Negative } \\
\text { Binomial }\end{array}$ & OLS & OLS \\
\hline $\begin{array}{l}\text { Fixed or Random } \\
\text { Country Effects }\end{array}$ & random & fixed & fixed & fixed \\
\hline \# of obs. & 70 & 70 & 1,800 & 418 \\
\hline \# of countries & 30 & 30 & 118 & 93 \\
\hline $\mathrm{R}^{2}$ (within) & & & 0.02 & 0.03 \\
\hline
\end{tabular}

Robust standard errors are in parentheses; ** indicates significance at the $5 \%$ level; and * indicates significance at the $10 \%$ level.

Table 8 replicates the analysis of table 2 , including the robust determinants of IMF programs as control variables in addition to the number of conditions and, respectively, the size of the loan. Arguably, the determinants of IMF programs will also to some extent determine the size of the loan and the number of conditions. Note, however, that we can not include the election and past agreement variables to the number of conditions regressions, as there are not enough observations in our sample.

Columns 1-2 report the Negative Binomial Regression results for the number of conditions, both with and without including fixed country effects. The results show that the covariates are insignificant in most specification. The exception is investment, which reduces the number of conditions at least at the five percent level of significance. 
Generally speaking, however, conditionality is hard to explain. The number of conditions is random with respect to most variables that predict IMF participation.

With respect to UNSC membership, the coefficient has the expected negative coefficient and is significant at the ten percent level at least. Regarding the quantitative impact of UNSC membership, the results show that UNSC membership reduces the number of conditions by about half of a condition. ${ }^{41}$ What is the mechanism by which UNSC membership has this effect? As devising the number of conditions is the authority of IMF staff, either the staff lower the number of conditions to appeal to the "lowest common denominator" of Executive Board views, or at some point Executive Directors representing the G7 usurp the staff to soften the number of conditions for UNSC members.

Summarizing, we find strong evidence that UNSC membership reduces the number of conditions a country has to accept under an IMF program - although the value of the quantitative impact varies with model and specification. Note that the small number of countries among our sample serving on the UNSC makes these results rather preliminary. Also, our covariates have been chosen in line with the previous literature on the determinants of IMF programs. While there is reason to expect these variables to also impact on conditionality, our results show that the model does not seem to be entirely accurate. Finally, we did not take the selection into Fund programs into account - clearly, the number of conditions can only be observed while under a program, and this might produce a bias in our results. More research is needed and will be more fruitful as transparency pressures continue to make the IMF a more open institution. The Fund must release clear data on conditionality.

Columns 3 and 4, finally, report results for the size of IMF loans (in percent of GDP). While column 3 includes the amount of net new IMF loans disbursed, column 4 reports the loan size the IMF and the borrower agree upon at program approval. ${ }^{42}$ The sample analyzing loan approval is restricted to countries that sign a program in the respective year; net IMF loans refer to the full sample. Regarding our covariates, the

\footnotetext{
${ }^{41}$ We also replicated the results with OLS. While the negative impact of UNSC membership remains significant at the ten percent level, the quantitative impact is substantially greater, according to the OLS results.

${ }^{42}$ New net IMF loans disbursed are taken from World Development Indicators (2004); amounts agreed come from International Financial Statistics (2005).
} 
results show that IMF loans are more likely to be disbursed when a country has higher international reserves, with a coefficient being significant at the five percent level. Significantly larger IMF loans are agreed upon, when countries run out of reserves, and debt service is high. The results also show that temporary UNSC membership has no impact on IMF loans disbursed or approved, with both coefficients being completely insignificant. ${ }^{43}$ This may be because, while an IMF arrangement with soft conditionality is typically put in place for developing countries serving on the UNSC so that an IMF loan can be used to entice them, the actual disbursement of loans may depend on many other factors, such as the actual voting record of the UNSC member, the sensitivity of a voting matter to a particular country, or how closely allied the country already is with the West.

We, thus, conclude the following from our analysis: non-permanent members of the UNSC are more likely than other countries to receive a loan from the IMF. The IMF arrangement is likely to happen during the first year of the two-year UNSC term. It is likely to have fewer conditions attached than IMF arrangements with non-UNSC members, although the actual loan size is not impacted by UNSC membership.

\section{Conclusions}

Our results contribute to the growing literature showing that the IMF is to a great extent employed as a tool of foreign policy by its major stakeholders. Whether used to bribe or reward, IMF loans are funneled not just to developing countries facing economic crises, but also to politically important developing countries, such as those serving a term on the UN Security Council. We do not know whether the temporary UNSC members increase their request for financing - having increased confidence the IMF would approve the loan - or, alternatively, whether the Fund's major shareholders take initiative. In any case, IMF loans are one mechanism by which the major stakeholders of the IMF - mainly the US, but also Japan, Germany, France and the United Kingdom - can win the favor of voting members of the UN Security Council.

This is not what the institution was intended to be used for. Originally, the IMF was set up to facilitate international trade and national prosperity by helping to manage

\footnotetext{
${ }^{43}$ Note that this remains true when the fixed country effects are omitted.
} 
balance of payments through loans. The failure of IMF programs, which involve both loans and policy conditions designed to address the balance of payments, is blamed by many on the design of programs and on the failure of countries to adopt IMF reforms.

Yet, the governance of the IMF is also to blame. Part of the failure of the IMF is that its loans have been used not to promote development or to even manage balance of payments problems. Instead, the loans have been used as a political tool, funneled to countries regardless of economic policy or economic need.

Those arguing for the reform of IMF governance call for a redistribution of vote shares so that recipient countries have a greater voice. ${ }^{44}$ But even the most extreme suggestions still leave the US with the largest vote share. Moreover, changing vote shares would not change the fact that the IMF can still be used to achieve foreign policy objectives; it would just change the players who get to use the IMF to pursue foreign policy objectives.

To prevent the abuse of the IMF, the institution's main governing body - the Executive Board - must be made independent, much like central bank presidents have been given independence domestically in many countries. The Directors who sit on the IMF Executive Board should be appointed for long, non-renewable terms, which do not coincide with the election cycles of the major shareholders. Only when the governance of the IMF is freed from pursuing foreign policy objectives can we expect the institution function according to its mandate.

Similarly, we propose institutional changes to reform the UNSC. Reforming the IMF alone will still leave other avenues by which governments can influence votes on the UNSC, such as direct foreign aid. Our suggestions draw on the literature on democracy and accountability (see, e.g., Przeworski et al. 1999). One problem with elected members of the UNSC is that, while seats are reserved for specific regions or groups - Africa, Asia, Eastern Europe, Latin America, and Advance Industrial Countries - the members really just represent their own country. This makes it easy to know which country to bribe. Another problem is that representatives are term limited. Thus, there is no incentive to try to represent the regional interest. There is no possibility of reelection, so representatives rightfully seek whatever rents they can achieve while in office.

${ }^{44}$ See Bird and Rowlands (2006) for a recent discussion. Also see Buira (2005). 
Perhaps representation would be better served if the governments of the countries from each group elected their representatives for renewable terms, just like most countries coalesce to elect their Executive Directors at the IMF. To win reelection, a representative on the UNSC would have to vote according to the preferences of the governments in his region. Of course, such a representative would be subject to influence, but representatives doing a bad job of representing their region could be thrown out of office, while representatives doing a good job could win continued reelection. Countries like the US might still try to buy votes, but, for example, instead of buying the votes of the representative from Zimbabwe who has no hope of reelection, the US would have to buy the votes of an African representative, who is responsible to 54 countries and who may prefer reelection to bribes.

The key to reforming both the IMF and the UNSC is to address the incentives of its voting members. In the meantime, we can expect IMF loans to continue to be abused by powerful countries to influence UNSC members serving temporary terms, representing hungry developing countries desperate to trade votes for aid. 


\section{References}

Alesina, Alberto and David Dollar, 2000, Who Gives Foreign Aid to Whom and Why? Journal of Economic Growth 5: 33-64.

Alesina, Alberto and Beatrice Weder, 2002, Do Corrupt Governments Receive Less Foreign Aid? American Economic Review 92, 4: 1126-1137.

Andersen, Thomas B.; Henrik Hansen and Markussen, Thomas, 2006, US politics and World Bank IDA-lending, Journal of Development Studies, forthcoming.

Baker, James A., III, 1995, The Politics of Diplomacy: Revolution, War and Peace: 1989-1992, New York: Putnam's.

Ball, Richard and Christopher Johnson, 1996, Political, Economic, and Humanitarian Motivations for PL 480 Food Aid: Evidence from Africa, Economic Development and Cultural Change 44, 3: 515-537.

Barro, Robert J. and Jong-Wha Lee, 2005, IMF-Programs: Who Is Chosen and What are the Effects? Journal of Monetary Economics 52: 1245-1269.

Beck, Nathaniel; Jonathan N. Katz and Richard Tucker, 1998, Taking Time Seriously: Time- Series-Cross-Section Analysis with a Binary Dependent Variable, American Journal of Political Science 42: 1260-88.

Beck, Thorsten; George Clarke; Alberto Groff; Philip Keefer and Patrick Walsh, 1999, New tools and new tests in comparative political economy: The Database of Political Institutions, Development Research Group, The World Bank, Groff: Federal Department of Foreign Affairs (Switzerland).

Bennis, Phyllis, 1997, The United Nations and Palestine: partition and its aftermath - UN stance on Palestine's displacement by creation of Israel, Arab Studies Quarterly 19(3): 47-77.

Bernstein, Samuel J. and Eugene J. Alpert, 1971, Foreign Aid and Voting Behavior in the United Nations: The Admission of Communist China, Orbis 15, 3: 963-977.

Bird, Graham, 1996, The International Monetary Fund and Developing Countries: A Review of the Evidence and Policy Options, International Organization 50: 477511. 
Bird, Graham, Mumtaz Hussain and Joseph P. Joyce, 2004, Many Happy Returns? Recidivism and the IMF, Journal of International Money and Finance 23(2): 231251.

Bird, Graham and Dane Rowlands, 2001, IMF Lending: How Is It Affected by Economic, Political and Institutional Factors? Journal of Policy Reform 4, 3: 243270.

Bird, Graham and Dane Rowlands, 2006, IMF Quotas: Constructing An International Organization Using Inferior Building Blocks, The Review of International Organization, 1, 2: 153-171.

Boockmann, Bernhard and Axel Dreher, 2006, How Do Countries Vote? An Empirical Analysis of Roll-Call Voting in the UN General Assembly, ZEW Mannheim and ETH Zurich.

Boschini, Anne and Anders Olofsgard, 2001, Foreign Aid: An Instrument for Fighting Poverty or Communism? Journal of Development Studies.

Broz, J. Lawrence and Michael B. Hawes, 2006, US Domestic Politics and International Monetary Fund Policy, in: Darren Hawkins, David A. Lake, Daniel Nielson, and Michael J. Tierney (eds.), Delegation and Agency in International Organizations, Cambridge University Press, forthcoming.

Buira, Ariel, 2005, The Bretton Woods Institutions: Governance without Legitimacy? In Ariel Buira (ed.), Reforming the Governance of the IMF and the World Bank. London: Anthem Press. Pp 7-44.

Bulíř, Aleš and Soojin Moon, 2004, Is Fiscal Adjustment More Durable When the IMF is Involved? Comparative Economic Studies 46: 373-399.

Chamberlain, G., 1980, Analysis of Covariance with Qualitative Data, Review of Economic Studies 47: 225-238.

Cheibub, Jose Antonio and Jennifer Gandhi, 2004, Classifying Political Regimes: A SixFold Measure of Democracies and Dictatorships, Paper prepared for annual meeting of the American Political Science Association, Chicago, September 2004.

Doyle, Michael W, 2001, The New Interventionism, Metaphilosophy 32: 212-235.

Dreher, Axel, 2004, A Public Choice Perspective of IMF and World Bank Lending and Conditionality, Public Choice 119, 3-4: 445-464. 
Dreher, Axel and Nathan M. Jensen, 2007, Independent Actor or Agent? An Empirical Analysis of the Impact of US Interests on IMF Conditions, The Journal of Law and Economics 50, 1, forthcoming.

Dreher, Axel and Jan-Egbert Sturm, 2006, Do IMF and World Bank Influence Voting in the UN General Assembly? KOF Working Paper 137, ETH Zurich.

Dreher, Axel, Rainer Thiele and Peter Nunnenkamp, 2006, Does US Aid Buy UN General Assembly Votes? A Disaggregated Analysis, KOF Working Paper 138, ETH Zurich.

Dreher, Axel and Roland Vaubel, 2004a, Do IMF and IBRD cause moral hazard and political business cycles? Evidence from panel data, Open Economies Review 15(1): 5-22 .

Dreher, Axel and Roland Vaubel, 2004b, The Causes and Consequences of IMF Conditionality, Emerging Markets Finance and Trade 40, 3: 26-54.

Eichengreen, Barry, 1998, Globalizing Capital: A History of the International Monetary System. Princeton: Princeton University Press.

Eldar, Ofer, 2004, Vote Trading in International Organizations, New York University School of Law, mimeo.

Faini, Riccardo and Enzo Grilli, 2004, Who Runs the IFIs? CEPR Discussion Paper No. 4666.

Fleck, Robert K. and Christopher Kilby, 2006, How Do Political Changes Influence US Bilateral Aid Allocations? Evidence from Panel Data, Review of Development Economics 10, 2: 210-223.

Fratianni, Michele and John Pattison, 2005, Who is Running the IMF: Critical Shareholders or the Staff? In: P. de Gijsel and H. Schenk (eds), Multidisciplinary Economics: The Birth of a New Economics Faculty in the Netherlands, Berlin: Springer, 279-292.

Frey, Bruno S. and Friedrich Schneider, 1986, Competing Models of International Lending Activity, Journal of Development Economics 20, 3: 225-245.

Gisselquist, D., 1981, The Political Economy of International Bank Lending, New York, Praeger. 
Gould, Erica R, 2003, Money Talks: Supplemental Financiers and International Monetary Fund Conditionality, International Organization 57, 3: 551-586.

Green, Donald; Soo Yeon Kim, and David Yoon, 2001, Dirty Pool, International Organization 55: 441-468.

Harrigan, Jane; Chengang Wang and Hamed El-Said, 2006, The Economic and Political Determinants of IMF and World Bank Lending in the Middle East and North Africa, World Development 34, 2: 247-270.

International Monetary Fund, 2001, Structural Conditionality in Fund-Supported Programs, February 16, http://www.imf.org.

International Monetary Fund, 2005, International Financial Statistics, CD-Rom. Washington, DC: IMF.

Ivanova, Anna; Wolfgang Mayer; Alex Mourmouras and George Anayiotos, 2005, What Determines the Implementation of IMF-Supported Programs? In: Ashoka Mody and Alessandro Rebucci (eds.), IMF-Supported Programs: Assessing Program Design, Implementation, and Effectiveness, Washington DC: International Monetary Fund, forthcoming.

Kato, Masakatsu, 1969, A Model of US Foreign Aid Allocation: An Application of a Rational Decision-Making Scheme, in: John E. Mueller (ed.), Approaches to Measurement in International Relations, Appleton Century Croft, New York.

Kegley, Charles W. Jr. and Steven W. Hook, 1991, US Foreign Aid and U.N. Voting:

Did Reagan's Linkage Strategy Buy Defence or Defiance? International Studies Quarterly 35, 3: 295-312.

Kilby, Christopher, 2006, Donor Influence in MDBs: The Case of the Asian Development Bank, The Review of International Organizations 1, 2: 173-195.

Kuziemko, Ilyana and Eric Werker, 2005, How much is a Seat on the Security Council Worth? Foreign Aid and Bribery at the United Nations, Journal of Political Economy, forthcoming.

Kwitny, Jonathan, 1983, US Charged with bias in IMF votes, Wall Street Journal, May 18: 39.

Leamer, Edward E., 1983, Let's take the con out of econometrics, American Economic Review 73, 31-43. 
Levine, Ross and David Renelt, 1992, A sensitivity analysis of cross-country growth regressions, American Economic Review 82, 942-963.

Levitt, Steven D. and James M. Snyder, Jr., 1997, The Impact of Federal Spending on House Election Outcomes, Journal of Political Economy 105, 1: 30-53.

Loxley, J., 1986, Debt and Disorder: External Financing for Development, Boulder, Westview Press.

Lundborg, Per, 1998, Foreign Aid and International Support as a Gift Exchange, Economics \& Politics 10, 2: 127-142.

Malone, David, 1998, Decision-Making in the UN Security Council: The Case of Haiti, 1990-1997, New York: Oxford University Press.

Marchesi, Silvia, 2003, Adoption of an IMF Programme and Debt Rescheduling. An empirical analysis, Journal of Development Economics 70, 2: 403-423.

Momani, Bessma, 2004a, American politicization of the International Monetary Fund, Review of International Political Economy 11: 880-904.

Momani, Bessma, 2004b, The IMF, the US War on Terrorism, and Pakistan, Asian Affairs 31(1): 41-50.

Morey, Daniel and Brian Lai, 2003, Liberalism, Realism, and United Nations Voting: An Empirical Test of Contending Theories, Department of Political Science, University of Iowa, mimeo.

Morgenthau, H., 1962, A Political Theory of Foreign Aid, The American Political Science Review 56, 301-309.

Oatley, Thomas and Jason Yackee, 2004, American Interests and IMF Lending, International Politics 41, 3: 415-429.

Pilgar, J., 2002, How the Bushes Bribe the World, New Statesman, September 23.

Przeworski, Adam; Susan C. Stokes and Bernard Manin, 1999, Democracy, Accountability, and Representation. New York: Cambridge University Press.

Przeworski, Adam; Michael Alvarez; José Antonio Cheibub and Fernando Limongi, 2000, Democracy and Development: Political Regimes and Economic Well-being in the World, 1950-1990, New York: Cambridge University Press.

Przeworski, Adam and James Vreeland, 2000, The Effect of IMF Programs on Economic Growth, Journal of Development Economics 62: 385-421. 
Przeworski, Adam and James Vreeland, 2002, A Statistical Model of Bilateral Cooperation, Political Analysis 10: 101-112.

Rai, Kul B., 1972, Foreign Policy and Voting in the UN General Assembly, International Organization 26, 3: 589-594.

Rai, Kul B., 1980, Foreign Aid and Voting in the UN General Assembly, 1967-1976, Journal of Peace Research 17, 3: 269-277.

Rieffel, Lex, 2003, Restructuring Sovereign Debt: The Case for ad-hoc Machinery, Brookings Institution Press, Washington, D.C.

Rosendorff, B. Peter and James Raymond Vreeland, 2006, Democracy and Data Dissemination: The Effect of Political Regime on Transparency. Mimeo.

Russett, Bruce. Ed., 1997, The Once and Future Security Council. New York: St. Martin's Press.

Ruttan, Vernon W., 1996, United States Development Assistance Policy: The Domestic Politics of Foreign Economic Aid, The Johns Hopkins University Press, Baltimore.

Sala-i-Martin, Xavier, 1997, I just ran two millions regressions, American Economic Review 87, 2: 178-183

Sala-i-Martin, Xavier; Gernot Doppelhofer and Ronald I. Miller, 2004, Determinants of long-term growth: A Bayesian averaging of classical estimates (BACE) approach, American Economic Review 94, 4: 813-835.

Sandler, Todd, and Keith Harley, 1999, The Political Economy of NATO: Past, Present, and into the 21st Century, Cambridge: Cambridge University Press.

Schneider, Friedrich; Bruno S. Frey; Henrik Horn and Torsten Persson, 1985, A Formulation and Test of a Simple Model of World Bank Behavior, Weltwirtschaftliches Archiv 121, 3: 438-447.

Sexton, Edwin A. and Terence N. Decker, 1992, US Foreign Aid: Is It for Friends, Development or Politics, The Journal of Social, Political and Economic Studies 17(3 \& 4): 303-315.

Smith, Alastair and James Raymond Vreeland, 2006, The Survival of Political Leaders and IMF Programs. In Gustav Ranis, James Vreeland, and Stephen Kosack (eds.), 
Globalization and the Nation State: The Impact of the IMF and the World Bank. New York: Routledge.

Stein, Howard, 1992, Economic Policy and the IMF in Tanzania: Conditionality, Conflict, and Convergence, in: Horace Campbell and Howard Stein (eds.), Tanzania and the IMF: The Dynamics of Liberalization, Boulder: Westview Press: 59-83.

Stone, Randall W., 2002, Lending Credibility: The International Monetary Fund and the Post-Communist Transition, Princeton, NJ: Princeton University Press.

Stone, Randall W., 2004, The Political Economy of IMF Lending in Africa, American Political Science Review 98, 4: 577-592.

Sturm, Jan-Egbert and Jakob de Haan, 2001, How Robust is Sala-i-Martin's Robustness Analysis, University of Groningen, mimeo.

Sturm, Jan-Egbert, Berger, Helge and Jakob de Haan, 2005, Which Variables Explain Decisions on IMF Credit? An Extreme Bounds Analysis, Economics \& Politics $17(2), 177-213$.

Temple, Jonathan, 2000, Growth Regressions and What the Textbooks Don't Tell You, Bulletin of Economic Research 52, 3: 181-205.

Thacker, Strom C., 1999, The High Politics of IMF Lending, World Politics 52: 38-75.

Trudel, Robert, 2005, Effects of Exchange Rate Regime on IMF Program Participation, Review of Policy Research 22, 6: 919-36.

United Nations. 2006. United Nations Security Council Members. http://www.un.org/sc/members.asp

Vaubel, Roland, 1986, A Public Choice Approach to International Organisation, Public Choice 51: 39-57.

Vaubel, Roland, 1991, The Political Economy of the International Monetary Fund: A Public Choice Analysis, in: R. Vaubel and T.D. Willett (eds.), The Political Economy of International Organizations: A Public Choice Approach. Boulder, Co., Westview Press: 204-244.

Vaubel, Roland, 1996, Bureaucracy at the IMF and the World Bank: A Comparison of the Evidence, The World Economy 19: 185-210.

Voeten, Erik, 2000, Clashes in the Assembly, International Organization 54, 2: 185-215. 
Voeten, Erik, 2001, Outside Options and the Logic of Security Council Action, American Political Science Review, 95, 4: 845-858.

Voeten, Erik, 2004, Documenting Votes in the UN General Assembly, Political Science and International Affairs, The George Washington University.

Volden C. and C.J. Carrubba, 2004, The Formation of Oversized Coalitions in Parliamentary Democracies, American Journal of Political Science 48(3): 521537.

Vreeland, James, 2003, The IMF and Economic Development, Cambridge: Cambridge University Press.

Vreeland, James, 2005, The International and Domestic Politics of IMF Programs, Yale University, mimeo.

Vreeland, James, 2006, The International Monetary Fund: Politics of Conditional Lending, forthcoming.

Wang, T.Y., 1999, US Foreign Aid and UN Voting: An Analysis of Important Issues, International Studies Quarterly 43, 1: 199-210.

Wittkopf, Eugene, 1973, Foreign Aid and United Nations Votes: A Comparative Study, The American Political Science Review 67, 3: 868-888.

Woods, Ngaire, 2003, The United States and the International Financial Institutions: Power and Influence within the World Bank and the IMF, in: Foot, McFarlane and Mastanduno (Eds.), US Hegemony and International Organizations, Oxford: 92-114.

World Bank. 2004, World Development Indicators on CD-ROM. Washington, DC: The World Bank.

Zimmermann, Robert, 1993, Dollars, Diplomacy and Dependency - Dilemmas of US Economic Aid, Lynne Reinner Publishers Inc., Colorado. 


\section{Appendix A: Extreme Bounds Analysis (EBA)}

To examine both the sensitivity of our baseline model and the coefficients of our explanatory variables of interest to changes in model specification we apply (variants) of the so-called Extreme Bounds Analysis (EBA) as suggested by Leamer (1983) and Levine and Renelt (1992). EBA has been widely used in the economic growth literature. $^{45}$ The central difficulty in this research - which also applies to the research topic of the present paper - is that several different models may all seem reasonable given the data, but yield different conclusions about the parameters of interest. The EBA can be exemplified as follows. Equations of the following general form are estimated:

$$
Y=\alpha M+\beta F+\gamma Z+u,
$$

where $Y$ is the dependent variable; $M$ is a vector of 'standard' explanatory variables; $F$ is the variable of interest; $Z$ is a vector of up to three possible additional explanatory variables, which according to the literature may be related to the dependent variable; and $u$ is an error term. The extreme bounds test for variable $F$ states that if the lower extreme bound for $\beta$ - i.e. the lowest value for $\beta$ minus two standard deviations - is negative, while the upper extreme bound for $\beta$ - i.e. the highest value for $\beta$ plus two standard deviations - is positive, the variable $F$ is not robustly related to $Y$.

As argued by Temple (2000), it is rare in empirical research that we can say with certainty that one model dominates all other possibilities in all dimensions. In these circumstances, it makes sense to provide information about how sensitive the findings are to alternative modeling choices. The EBA provides a relatively simple means of doing exactly this. Still, the EBA has been criticized in the literature. Sala-i-Martin (1997) argues that the test applied in the Extreme Bounds Analysis poses too rigid a threshold in most cases. If the distribution of $\beta$ has some positive and some negative support, then one is bound to find at least one regression for which the estimated coefficient changes sign if enough regressions are run. We will therefore not only report the extreme bounds, but also the percentage of the regressions in which the coefficient of the variable $F$ is significantly different from zero at the 5 percent level. Moreover, instead of analyzing just the extreme bounds of the estimates of the coefficient of a particular variable, we follow Sala-i-Martin's (1997) suggestion to analyze the entire distribution. Following this

\footnotetext{
${ }^{45}$ See, e.g. Levine and Renelt (1992), Sala-i-Martin (1997).
} 
suggestion, we not only report the unweighted parameter estimate of $\beta$ and its standard deviation but also the unweighted cumulative distribution function $(\operatorname{CDF}(0))$, i.e. the fraction of the cumulative distribution function lying on one side of zero. We will base our conclusions on the Sala-i-Martin variant of the EBA. ${ }^{46}$

46 Sala-i-Martin (1997) proposes using the (integrated) likelihood to construct a weighted $\mathrm{CDF}(0)$. However, the varying number of observations in the regressions due to missing observations in some of the variables poses a problem. Sturm and de Haan (2001) show that as a result this goodness of fit measure may not be a good indicator of the probability that a model is the true model and the weights constructed in this way are not equivariant for linear transformations in the dependent variable. Hence, changing scales will result in rather different outcomes and conclusions. We therefore restrict our attention to the unweighted version. Furthermore, for technical reasons - in particular our unbalanced panel setup - we are unable to use the extension of this approach called Bayesian Averaging of Classical Estimates (BACE) as introduced by Sala-i-Martin, Doppelhofer and Miller (2004). 


\section{Appendix B: Sources and Definitions}

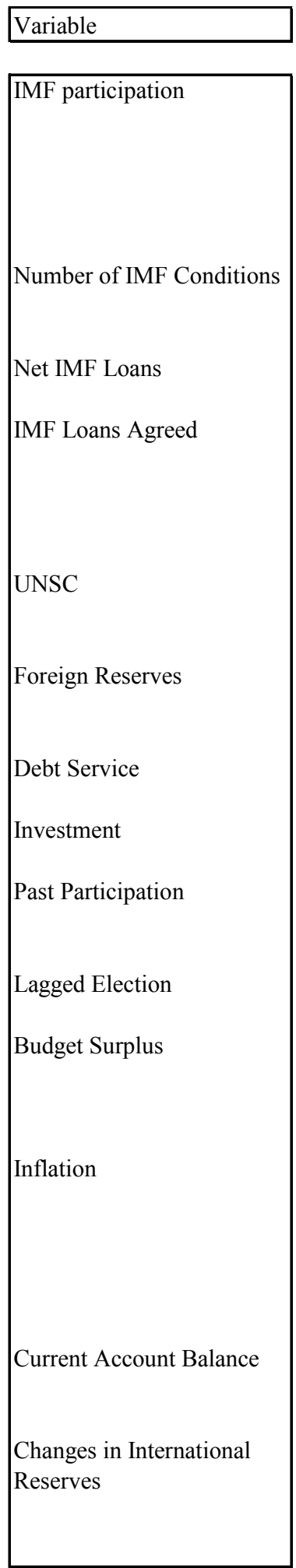

\section{Description}

Dummy coded 1 if a country participates in an IMF program during part of the year under Stand-by, Extended Fund Facility, Structural Adjustment Facility, and Extended Structural Adjustment Facility/Poverty Reduction and Growth Facility, and 0 otherwise.

Number of IMF conditions from 206 IMF letters of intent with 38 countries between October 1997 and March 2003.

Disbursements of loans and credits less repayments of principal in percent of GDP. Loans agreed under Stand-by, Extended Fund Facility, Structural Adjustment Facility, and Extended Structural Adjustment Facility/Poverty Reduction and Growth Facility (in percent of GDP)

Dummy coded 1 if a country is a non-permanent member of the United Nations Security Council, and 0 otherwise.

Gross international reserves in terms of the number of months of imports of goods and services which could be paid for.

Total debt service outstanding in percent of GNI.

Private and public gross national investment as a share of gross domestic product (GDP).

Dummy coded 1 for countries that have previously participated in IMF programs and 0 otherwise.

Dummy variable coded 1 if elections were held the previous year and 0 otherwise.

Overall budget balance is current and capital revenue and official grants received, less total expenditure and lending minus repayments for central government in percent of GDP.

Inflation as measured by the consumer price index reflects the annual percentage change in the cost to the average consumer of acquiring a fixed basket of goods and services that may be fixed or changed at specified intervals, such as yearly. The Laspeyres formula is generally used. Sum of net exports of goods, services, net income, and net current transfers (in percent of GDP).

Changes in net reserves is the net change in a country's holdings of international reserves resulting from transactions on the current, capital, and financial accounts (in percent of

\section{Source}

IMF Annual Report (various years)

Dreher and Vaubel (2004b)

World Bank (2004)

IMF (2005)

United Nations (2006)

World Bank (2004)

World Bank (2004)

Przeworski et al. (2000)

IMF Annual Report (various years)

Beck et al. (1999)

World Bank (2004)

World Bank (2004)

World Bank (2004)

World Bank (2004) 
Appendix B (continued)

\begin{tabular}{|l|}
\hline Variable \\
\hline GDP per capita \\
Growth \\
Regime \\
$\log ($ checks $)$ \\
\hline
\end{tabular}

Description

Measured in 1995 PPP dollars

Growth rate of GDP per capita.

Dummy variable coded 1 for dictatorships and 0 for democracy.

Log of the number of checks and balances.
Source

Przeworski et al. (2000)

Przeworski et al. (2000)

Przeworski et al. (2000)

Beck et al. (1999)

\section{Appendix C: Participation in IMF programs, descriptive statistics}

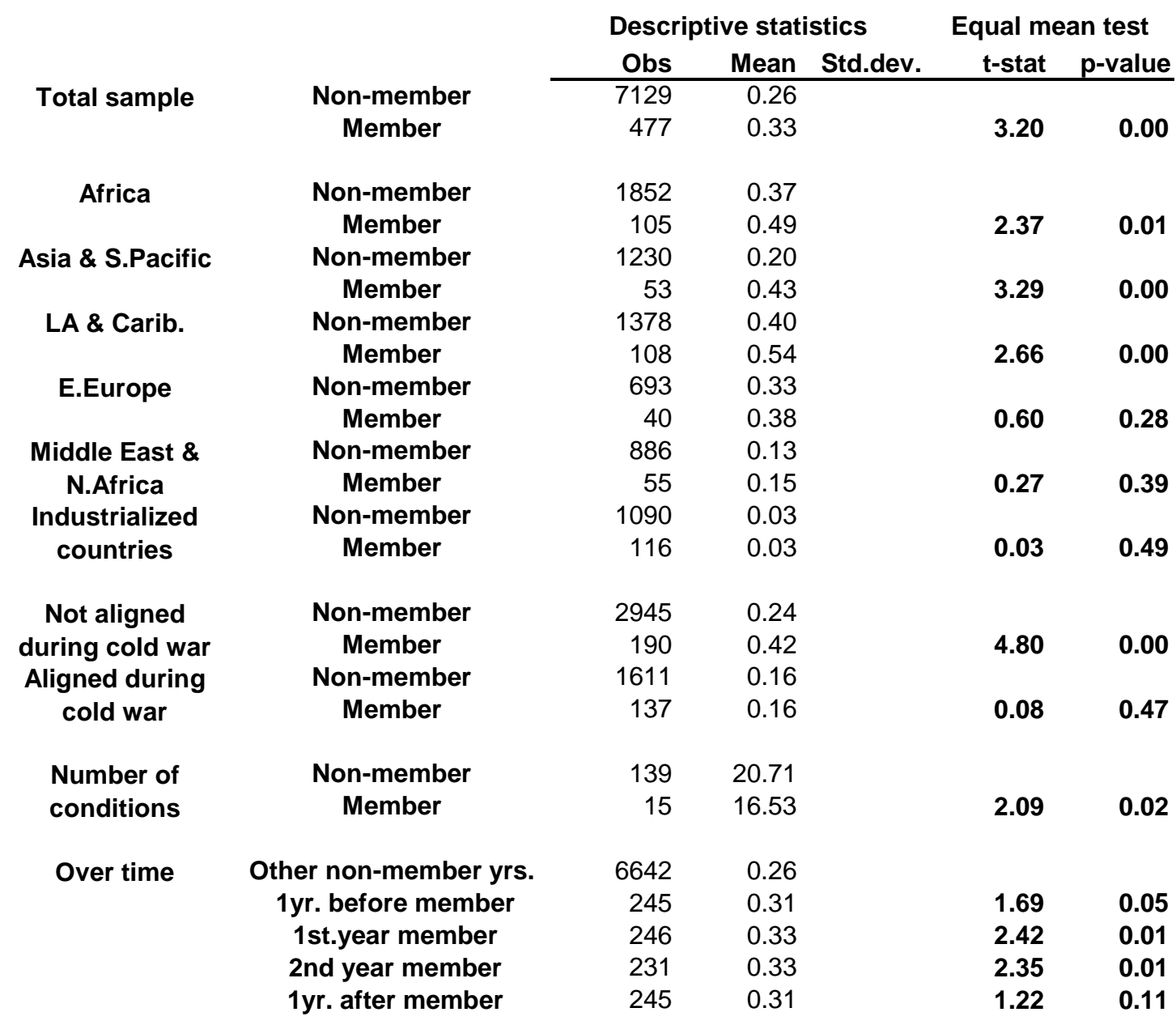

The equal means tests allows for unequal variances. 


\section{Appendix D: Descriptive Statistics}

\begin{tabular}{|l|}
\hline Variable \\
\hline IMF participation \\
Number of IMF Conditions \\
Net IMF Loans \\
IMF Loans Agreed \\
UNSC \\
Foreign Reserves \\
Debt Service \\
Investment \\
Past Participation \\
Lagged Election \\
Budget Surplus \\
Inflation \\
Current Account Balance \\
Changes in International Reserves \\
GDP per capita \\
Growth \\
Regime \\
log(checks)
\end{tabular}

\begin{tabular}{|c|}
\hline Mean \\
\hline 0.27 \\
20.28 \\
0.04 \\
0.47 \\
0.06 \\
3.44 \\
17.22 \\
15.50 \\
0.48 \\
0.22 \\
-3.26 \\
43.96 \\
-4.58 \\
-0.01 \\
5746 \\
2.94 \\
0.61 \\
0.61 \\
\hline
\end{tabular}

\begin{tabular}{|c|c|}
\hline Minimum & Maximum \\
\hline 0.00 & 1.00 \\
\hline 5.00 & 78.00 \\
\hline-3.77 & 12.86 \\
\hline 0.00 & 23.27 \\
\hline 0.00 & 1.00 \\
\hline 0.00 & 25.36 \\
\hline 0.00 & 152.27 \\
\hline-3.46 & 101.13 \\
\hline 0.00 & 1.00 \\
\hline 0.00 & 2.00 \\
\hline-64.49 & 58.71 \\
\hline-100.00 & 23773.13 \\
\hline-894.54 & 56.70 \\
\hline-0.48 & 0.49 \\
\hline 281 & 50092 \\
\hline-97.79 & 2294.03 \\
\hline 0.00 & 1.00 \\
\hline 0.00 & 2.89 \\
\hline
\end{tabular}

Standard Deviation

\begin{tabular}{|c|}
\hline 0.44 \\
11.94 \\
0.52 \\
1.40 \\
0.25 \\
2.98 \\
14.23 \\
9.32 \\
0.50 \\
0.42 \\
5.84 \\
484.36 \\
20.78 \\
0.04 \\
5891 \\
38.95 \\
0.49 \\
0.66 \\
\hline
\end{tabular}




\section{CESifo Working Paper Series}

(for full list see www.cesifo-group.de)

1744 Markku Lanne and Helmut Luetkepohl, Identifying Monetary Policy Shocks via Changes in Volatility, June 2006

1745 Timo Trimborn, Karl-Josef Koch and Thomas M. Steger, Multi-Dimensional Transitional Dynamics: A Simple Numberical Procedure, June 2006

1746 Vivek H. Dehejia and Yiagadeesen Samy, Labor Standards and Economic Integration in the European Union: An Empirical Analysis, June 2006

1747 Carlo Altavilla and Paul De Grauwe, Forecasting and Combining Competing Models of Exchange Rate Determination, June 2006

1748 Olaf Posch and Klaus Waelde, Natural Volatility, Welfare and Taxation, June 2006

1749 Christian Holzner, Volker Meier and Martin Werding, Workfare, Monitoring, and Efficiency Wages, June 2006

1750 Steven Brakman, Harry Garretsen and Charles van Marrewijk, Agglomeration and Aid, June 2006

1751 Robert Fenge and Jakob von Weizsäcker, Mixing Bismarck and Child Pension Systems: An Optimum Taxation Approach, June 2006

1752 Helge Berger and Michael Neugart, Labor Courts, Nomination Bias, and Unemployment in Germany, June 2006

1753 Chris van Klaveren, Bernard van Praag and Henriette Maassen van den Brink, A Collective Household Model of Time Allocation - a Comparison of Native Dutch and Immigrant Households in the Netherlands, June 2006

1754 Marko Koethenbuerger, Ex-Post Redistribution in a Federation: Implications for Corrective Policy, July 2006

1755 Axel Dreher, Jan-Egbert Sturm and Heinrich Ursprung, The Impact of Globalization on the Composition of Government Expenditures: Evidence from Panel Data, July 2006

1756 Richard Schmidtke, Private Provision of a Complementary Public Good, July 2006

1757 J. Atsu Amegashie, Intentions and Social Interactions, July 2006

1758 Alessandro Balestrino, Tax Avoidance, Endogenous Social Norms, and the Comparison Income Effect, July 2006

1759 Øystein Thøgersen, Intergenerational Risk Sharing by Means of Pay-as-you-go Programs - an Investigation of Alternative Mechanisms, July 2006 
1760 Pascalis Raimondos-Møller and Alan D. Woodland, Steepest Ascent Tariff Reforms, July 2006

1761 Ronald MacDonald and Cezary Wojcik, Catching-up, Inflation Differentials and Credit Booms in a Heterogeneous Monetary Union: Some Implications for EMU and new EU Member States, July 2006

1762 Robert Dur, Status-Seeking in Criminal Subcultures and the Double Dividend of ZeroTolerance, July 2006

1763 Christa Hainz, Business Groups in Emerging Markets - Financial Control and Sequential Investment, July 2006

1764 Didier Laussel and Raymond Riezman, Fixed Transport Costs and International Trade, July 2006

1765 Rafael Lalive, How do Extended Benefits Affect Unemployment Duration? A Regression Discontinuity Approach, July 2006

1766 Eric Hillebrand, Gunther Schnabl and Yasemin Ulu, Japanese Foreign Exchange Intervention and the Yen/Dollar Exchange Rate: A Simultaneous Equations Approach Using Realized Volatility, July 2006

1767 Carsten Hefeker, EMU Enlargement, Policy Uncertainty and Economic Reforms, July 2006

1768 Giovanni Facchini and Anna Maria Mayda, Individual Attitudes towards Immigrants: Welfare-State Determinants across Countries, July 2006

1769 Maarten Bosker and Harry Garretsen, Geography Rules Too! Economic Development and the Geography of Institutions, July 2006

1770 M. Hashem Pesaran and Allan Timmermann, Testing Dependence among Serially Correlated Multi-category Variables, July 2006

1771 Juergen von Hagen and Haiping Zhang, Financial Liberalization in a Small Open Economy, August 2006

1772 Alessandro Cigno, Is there a Social Security Tax Wedge?, August 2006

1773 Peter Egger, Simon Loretz, Michael Pfaffermayr and Hannes Winner, Corporate Taxation and Multinational Activity, August 2006

1774 Jeremy S.S. Edwards, Wolfgang Eggert and Alfons J. Weichenrieder, The Measurement of Firm Ownership and its Effect on Managerial Pay, August 2006

1775 Scott Alan Carson and Thomas N. Maloney, Living Standards in Black and White: Evidence from the Heights of Ohio Prison Inmates, 1829 - 1913, August 2006 
1776 Richard Schmidtke, Two-Sided Markets with Pecuniary and Participation Externalities, August 2006

1777 Ben J. Heijdra and Jenny E. Ligthart, The Transitional Dynamics of Fiscal Policy in Small Open Economies, August 2006

1778 Jay Pil Choi, How Reasonable is the 'Reasonable' Royalty Rate? Damage Rules and Probabilistic Intellectual Property Rights, August 2006

1779 Ludger Woessmann, Efficiency and Equity of European Education and Training Policies, August 2006

1780 Gregory Ponthiere, Growth, Longevity and Public Policy, August 2006

1781 Laszlo Goerke, Corporate and Personal Income Tax Declarations, August 2006

1782 Florian Englmaier, Pablo Guillén, Loreto Llorente, Sander Onderstal and Rupert Sausgruber, The Chopstick Auction: A Study of the Exposure Problem in Multi-Unit Auctions, August 2006

1783 Adam S. Posen and Daniel Popov Gould, Has EMU had any Impact on the Degree of Wage Restraint?, August 2006

1784 Paolo M. Panteghini, A Simple Explanation for the Unfavorable Tax Treatment of Investment Costs, August 2006

1785 Alan J. Auerbach, Why have Corporate Tax Revenues Declined? Another Look, August 2006

1786 Hideshi Itoh and Hodaka Morita, Formal Contracts, Relational Contracts, and the Holdup Problem, August 2006

1787 Rafael Lalive and Alejandra Cattaneo, Social Interactions and Schooling Decisions, August 2006

1788 George Kapetanios, M. Hashem Pesaran and Takashi Yamagata, Panels with Nonstationary Multifactor Error Structures, August 2006

1789 Torben M. Andersen, Increasing Longevity and Social Security Reforms, August 2006

1790 John Whalley, Recent Regional Agreements: Why so many, why so much Variance in Form, why Coming so fast, and where are they Headed?, August 2006

1791 Sebastian G. Kessing and Kai A. Konrad, Time Consistency and Bureaucratic Budget Competition, August 2006

1792 Bertil Holmlund, Qian Liu and Oskar Nordström Skans, Mind the Gap? Estimating the Effects of Postponing Higher Education, August 2006 
1793 Peter Birch Sørensen, Can Capital Income Taxes Survive? And Should They?, August 2006

1794 Michael Kosfeld, Akira Okada and Arno Riedl, Institution Formation in Public Goods Games, September 2006

1795 Marcel Gérard, Reforming the Taxation of Multijurisdictional Enterprises in Europe, a Tentative Appraisal, September 2006

1796 Louis Eeckhoudt, Béatrice Rey and Harris Schlesinger, A Good Sign for Multivariate Risk Taking, September 2006

1797 Dominique M. Gross and Nicolas Schmitt, Why do Low- and High-Skill Workers Migrate? Flow Evidence from France, September 2006

1798 Dan Bernhardt, Stefan Krasa and Mattias Polborn, Political Polarization and the Electoral Effects of Media Bias, September 2006

1799 Pierre Pestieau and Motohiro Sato, Estate Taxation with Both Accidental and Planned Bequests, September 2006

1800 Øystein Foros and Hans Jarle Kind, Do Slotting Allowances Harm Retail Competition?, September 2006

1801 Tobias Lindhe and Jan Södersten, The Equity Trap, the Cost of Capital and the Firm's Growth Path, September 2006

1802 Wolfgang Buchholz, Richard Cornes and Wolfgang Peters, Existence, Uniqueness and Some Comparative Statics for Ratio- and Lindahl Equilibria: New Wine in Old Bottles, September 2006

1803 Jan Schnellenbach, Lars P. Feld and Christoph Schaltegger, The Impact of Referendums on the Centralisation of Public Goods Provision: A Political Economy Approach, September 2006

1804 David-Jan Jansen and Jakob de Haan, Does ECB Communication Help in Predicting its Interest Rate Decisions?, September 2006

1805 Jerome L. Stein, United States Current Account Deficits: A Stochastic Optimal Control Analysis, September 2006

1806 Friedrich Schneider, Shadow Economies and Corruption all over the World: What do we really Know?, September 2006

1807 Joerg Lingens and Klaus Waelde, Pareto-Improving Unemployment Policies, September 2006

1808 Axel Dreher, Jan-Egbert Sturm and James Raymond Vreeland, Does Membership on the UN Security Council Influence IMF Decisions? Evidence from Panel Data, September 2006 